\title{
Effectiveness of the GAEC cross compliance standard Maintenance of olive groves in good vegetative condition in avoiding the deterioration of habitats and land abandonment
}

\author{
Elena Santilli, ${ }^{1}$ Luca Lombardo, ${ }^{2}$ Maria E. Varlaro, ${ }^{1}$ Roberto Nannelli, ${ }^{3}$ Elena Gagnarli, ${ }^{3}$ \\ Caterina Briccoli Bati ${ }^{1}$ \\ ${ }^{1}$ Agricultural Research Council, Research Centre for Oliviculture and Olive Oil Industry, Rende; \\ ${ }^{2}$ Department of Crop Systems, Forestry and Environmental Sciences, University of Basilicata, Potenza; \\ ${ }^{3}$ Agricultural Research Council, Research Centre for Agrobiology and Pedology \\ (CRA-ABP), Firenze, Italy
}

\begin{abstract}
The last Common Agricultural Policy (CAP) reform (Council Regulation (EC) n. 1782/2003), coincided with the mandatory obligations of the principles of cross compliance, under which all compensatory payments given in the context of the former reform packages were replaced by a Single Payment Scheme (SPS), bound to fulfillment of certain requirements and minimum standards regarding the environment and animal welfare, as well as maintaining the land in good agricultural and environmental conditions. For the olive sector, where potential risks are mainly associated to the abandonment of groves in marginal areas with consequent negative environmental impact, it has been specifically established the standard 4.3 of the Good Agricultural and Environmental Conditions (GAEC) which concerns the Maintenance of olive groves and vines in good vegetative conditions. This GAEC standard was formulated to ensure a minimum level of land maintenance and to avoid the deterioration of habitats. To achieve these objectives it should be considered that a good vegetative development is strictly related to the care of the soil in which the plants grow. Erosion, organic matter and soil structure decay are the most commonly identified impacts for olive orchards, $30 \%$ of which are localized in areas with difficult orographic conditions. In this sense,
\end{abstract}

\footnotetext{
Correspondence: Caterina Briccoli Bati, Agricultural Research Council, Research Centre for Oliviculture and Olive Oil Industry (CRA-OLI) C.da Li Rocchi-Vermicelli, 87036 Rende (CS), Italy.

Tel. +39.0984.4052 - Fax: +39.0984.402099.

E-mail: caterina.briccolibati@entecra.it
}

Key words: Agri-environmental measures, CAP, cross compliance, oliviculture, standard 4.3.

Received for publication: 25 March 2011.

Accepted for publication: 4 May 2011

(C) Copyright E. Santilli et al., 2011

Under no circumstances figures can be used without prior written consent of the copyright owner.

Licensee PAGEPress, Italy

Italian Journal of Agronomy 2011; 6(s1):e15

doi:10.4081/ija.2011.6.s1.e15

This work is licensed under a Creative Commons Attribution NonCommercial 3.0 License (CC BY-NC 3.0). proper hydraulic and mechanical techniques, cover cropping, green manuring and timely pruning turns, are essential to minimize losses due to soil erosion, to limit the leaching of nutrients and to maintain the plant productivity. Furthermore, grinded pruning residues should be spread in situ and weeds, watersprouts and suckers should be periodically cut off in order to increase the atmospheric $\mathrm{CO}_{2}$ sequestration and soil organica matter $(\mathrm{OM})$ and to prevent wildfires risk and nutrients competition. The application of the standard 4.3 requires further investigations, because, while numerous studies have shown that pruning is essential for the production, there are not enough data on the influence that practicing this technique at least every five years could have on habitats maintenance and on olive trees vegetative development. This GAEC standard seems to be too generic and should be diversified according to different types of olive orchards.

\section{Introduction}

Olive (Olea europaea L.) is one of the most important and widespread fruit tree species in the world, whose origin is lost in prewritten history. Currently (Table 1), there are over 9.9 million hectares harvested -more than $90 \%$ of that in the Mediterranean basin- producing about 18 million Mg of olives and 3 million Mg of oil (FAO, 2009). Nevertheless, olive oil accounts for only $2 \%$ of total fat consumed in the world and for barely $3 \%$ within vegetable oils (Oil World, 2005), as well as $85 \%$ of whole consumption is still concentrated in the producer Countries of the Mediterranean area. In the EU-27, olive represents the main and most extensively cultivated permanent crop (38\%), with olive oil reaching the $1.3 \%$ share of the overall output value at producer prices of the agricultural industry (Eurostat, 2007; 2010). After millennium of substantial balance in Mediterranean crops, the olive grove agroecosystem has suffered in recent decades a major attack resulting from intensification, massive and indiscriminate use of agrochemicals, mainly for plant defence and production, provoking destabilization of the biological equilibrium and widespread environmental degradation (Iannotta, 2003). Moreover, during the 1980s and 1990s the Common Agricultural Policy (CAP) has encouraged, especially in Spain and Greece, the expansion of intensive plantation and increased the marginalization of traditional low-input systems with generally negative consequences for the environment: considerable reduction in the diversity and total number of flora and fauna, significant loss of wildlife habitat and erosion of the ecological infrastructure of the farmland (Kabourakis, 1999). In fact, production aid has been the main CAP tool to support olive farmers' income, particularly since 1998, 
when, after a transitional reform of the Common Market Organization (CMO), it became linked to current output for each producer (Duarte et al., 2006). The result is that, worldwide, intensive olive farming today represents $30 \%$ of acreage and $50 \%$ of total production, traditional farming $50 \%$ of acreage and $40 \%$ of production, and marginal olive farming $20 \%$ of acreage and $10 \%$ of production. With production intensification adverse environmental effects like erosion, decreased biodiversity, high water use and pollution, became a main feature of many olive growing areas in Italy, Spain, Greece, and Portugal (Beaufoy, 2001). At the same time, the abandonment of farming in marginal areas, driven by social and economic factors, was posing a serious threat to the farmed environment and to rural landscapes. The latest CAP reforms (referred to as Luxembourg agreement, or Fischler reform, Council Regulation (EC) n. 1782/2003) tried to respond to the double challenge of reducing agricultural pressures on the environment and favouring the delivery of environmental services by farming introducing agri-environmental measures (AEM). This reform comprises two principal headings of budgetary expenditure: market price support and direct income payments (Pillar 1), and a range of selective incentive payments targeting rural development (Pillar 2). An important cornerstone of the decoupling of direct payments from production is therefore the link between EU support for agriculture under the Single Payment Scheme and measures aimed at protecting the environment as well as achieving high standards in food safety, animal and plant health and welfare. Under the Single Payment Scheme farmers are required to respect the various Statutory Management Requirements (SMRs) set down in EU legislation (Directives and Regulations) on the environment, and to maintain land in Good Agricultural and Environmental Condition (GAEC). This is known as cross compliance. In this sense, the objective of cross compliance is to contribute to the development of sustainable agriculture and making the new CAP more compatible with the expectations of society at large and, in general, it is aimed at avoiding soil erosion, maintaining soil organic matter content and soil structure, ensuring proper conservation of land and landscape, and avoiding degradation of habitats. The aim of this work, conducted within the Efficond ${ }^{1}$ project is to provide an overview on the Italian oliviculture and to give guidance on cultivation techniques normally applied for the effective implementation of cross compliance, with particular reference to the standard 4.3 Maintenance of olive groves and vines in good vegetative conditions.

\section{Status of oliviculture in Italy}

Italy currently occupies the third place, after Spain and Tunisia, for the spread of olive with about 1.16 million hectares (around $98 \%$ in production) in primary culture which approximately represents $5.7 \%$ of the national utilized agricultural area (UAA), ranks second after Spain as oil producer and first as consumer (700,000 Mg per year) and importer (around 130,000 Mg per year) (ISTAT, 2010; FAO, 2009). Olive trees are farmed in 19 regions out of 20 , more consistently in the southern and insular ones (Figure 1) for a total number of orcharders differently estimated according to the identification criteria: i) about $1,050,000$ producers farming or developing activities of management and maintenance of olive groves (Mi.P.A.A.F., 2010); ii) 957,360 professional farms surveyed by Agea having access to CAP decoupling aid; iii) 775,783 agricultural farms estimated by ISTAT (2007a). with an even though minimal specialization in olive production.

${ }^{1}$ EFFICOND (EFF = environmental efficacy of COND = cross-compliance [Condizionalità in Italian] standards) is a project of the CRA (Agricultural Research Council) started in 2009 to answer the specific needs of the RRN (National Rural Network) to monitor and assess the environmental-protection measures imposed by the CAP on the national agricultural policy and implemented via the Regional Rural Development Plans (PSR). The project's main goals are the assessment of the Standards' environmental efficacy and the development of agrienvironmental indicators for the assessment of the Standards' efficacy at a national level.
Besides, the Italian olive germplasm bank contains over 500 varieties (Olea databases), approximately $42 \%$ of the world heritage, while according to Fiorino et al., (2005), over 800 cultivar are quoted in literature, even if it is to be said that the Italian olive growing is based at $90 \%$ on only 50 varieties. In line with these findings, it becomes clear the importance that this culture plays in economical, cultural and landscape terms. Nevertheless, oliviculture suffers from common problems to the whole Italian agriculture: structural retards and land abandonment. The greatest obstacles to renewal originate from the impossibility to uproot old unproductive olive trees and from the land structure of the Italian olive sector which is extremely fragmented, showing an average olive growing area of around one hectare per farm; $42 \%$ of the producers own less than 1 ha and $73 \%$ of them own less than 3 ha, furthermore, there are just a few producers with a surface larger than 100 ha (ISTAT, 2007b). In terms of olive trees number, over $60 \%$ of the farms own less than 100 trees, $78 \%$ of them less than 250 , producing a share equal to $46 \%$ of the total olive oil amount. Only $12 \%$ of the farms fall in the class interval from 250 to 500 plants and just $1.3 \%$ are equipped with over 1000 trees, producing $25 \%$ of the total olive oil amount (MiPAAF, 2010). It is easily explainable, apart from inherited

Table 1. Main olive producer in different countries, with related harvested area.

\begin{tabular}{lccc} 
Nation & $\begin{array}{c}\text { Harvested } \\
\text { area } \\
\text { (ha) }\end{array}$ & $\begin{array}{c}\text { Olive production } \\
\text { (Mg) }\end{array}$ & $\begin{array}{c}\text { Olive oil } \\
\text { production } \\
\text { (Mg) }\end{array}$ \\
\hline Spain & $2,500,000$ & $6,204,700$ & $1,199,200$ \\
Italy & $1,159,000$ & $3,600,500$ & 587,700 \\
\hline Greece & 800,000 & $2,444,230$ & 332,600 \\
Turkey & 727,513 & $1,290,654$ & 143,600 \\
\hline Syrian Arab Republic & 635,691 & 885,942 & 168,163 \\
Tunisia & $2,300,000$ & 750,000 & 150,000 \\
\hline Argentina & 52,000 & 160,000 & 22,700 \\
Australia & 20,000 & 62,655 & 5,638 \\
\hline United States of America & 12,545 & 38,830 & 2,700 \\
World & $9,922,836$ & $18,241,809$ & $2,907,985$ \\
\hline Soure: FAO data 2009 & & &
\end{tabular}

Source: FAO data 2009.

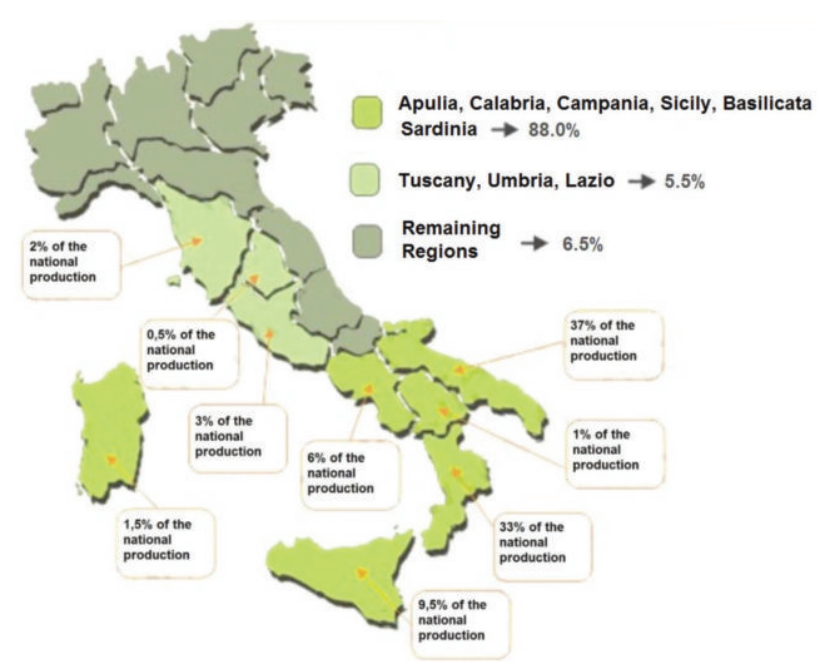

Figure 1. National production per year (based on ISTAT and ISMEA data, 2007). From: www.frantoionline.it 
reasons, considering that $30 \%$ of olive groves are localized in areas with difficult orographic conditions (Table 2). Another evidence of this fragmentation is the fact that in Italy there are over 6000 authorized oil mills, whereas in Spain they are about 1800 (ISMEA, 2009). From a farming system point of view, in Italy at least three main groups can be identified: abandoned or being abandoned olive groves with historicallandscape function, marginal olive groves characterized by specific factors defined by the Land Capability Classification (Klingebiel and Montgomery, 1961) as limiting the agricultural use of soil conferring marginality to the crop and productive olive groves.

Abandoned or being abandoned olive groves, including terraced ones (Figure 2), are no longer used for production purposes, but they have primarily acquired a landscape and historical function of protecting the

Table 2. Orographic distribution of olive groves in percentage.

\begin{tabular}{lccccc} 
& Plain & $\begin{array}{c}\text { Light } \\
\text { slope }\end{array}$ & $\begin{array}{c}\text { Heavy } \\
\text { slope } \\
(\mathbf{1 5 - 2 5 \% )})\end{array}$ & $\begin{array}{c}\text { Very } \\
\text { heavy } \\
\text { slope } \\
(>25 \%)\end{array}$ & Terrace \\
Italy & 39.2 & 42.2 & 9.7 & 0.6 & 8.3 \\
Central-Northern zone & 13.6 & 49.9 & 14.4 & 1.6 & 20.6 \\
\hline Southern zone & 49.1 & 39.2 & 7.9 & 0.3 & 3.5 \\
\hline
\end{tabular}

Source: Ismea, 2005
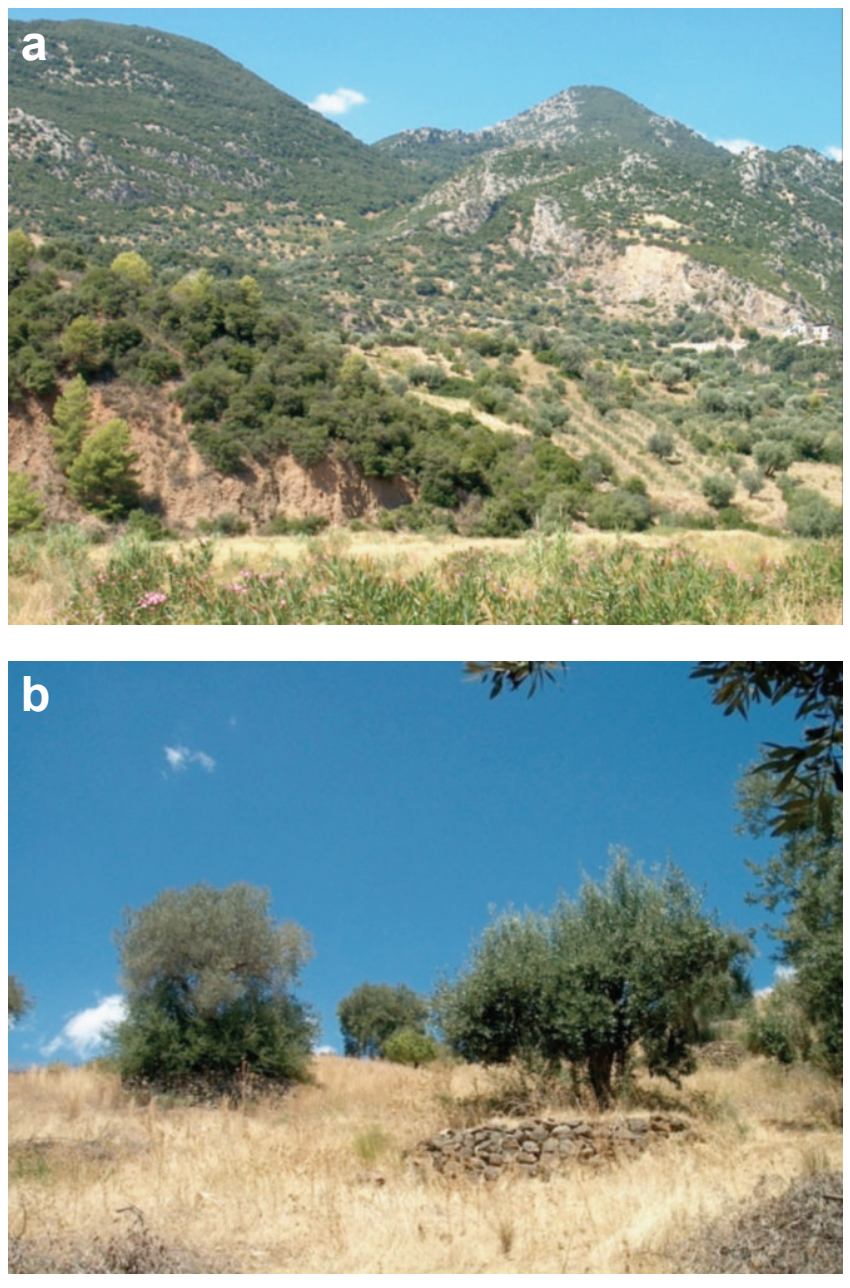

Figure 2. Abandoned or being abandoned mountainous (a) and terraced (b) olive groves. territory (e.g. control of runoff in steep slope areas) and maintaining the ecosystem. Therefore, they need both land management and weed control in order to avoid wildfire risk, cause of environmental degradation and biodiversity loss.

Marginal olive groves, often characterized by more or less pronounced slopes, should be managed so as to maintain soil fertility and to reduce erosion (Figure 3). The erosion processes in fact, directly contribute to soil degradation and sloping land destabilization, primary factor for the development of a productive agricultural activity. It's been demonstrated that the permanent cover cropping system can effectively solve these problems.

Productive olive groves: the cultivation techniques in olive farms aim to achieve the maximum productive and economic efficiency (Figure 4). To maximize the olive trees productivity it is necessary to optimize all cultural practices, especially pruning. The intensity of the cut varies according to age, vigor and plant cultivation system, and its purpose is to provide and maintain the appropriate form to enable a better management of the olive grove, as well as promoting the whole canopy aeration, lighting, photosynthesis and fruiting. Usually this technique is performed every 2 or 3 years maximum in late winter-early spring, while the removal of water sprouts is carried out annually. The management of soil, in this type of olive grove, is a function of the specific disposition of each plot and must be chosen according to the topography of the area (flat or hilly), in order to prevent the erosion of the most fertile soil layer and the deterioration of habitats (Table 2).
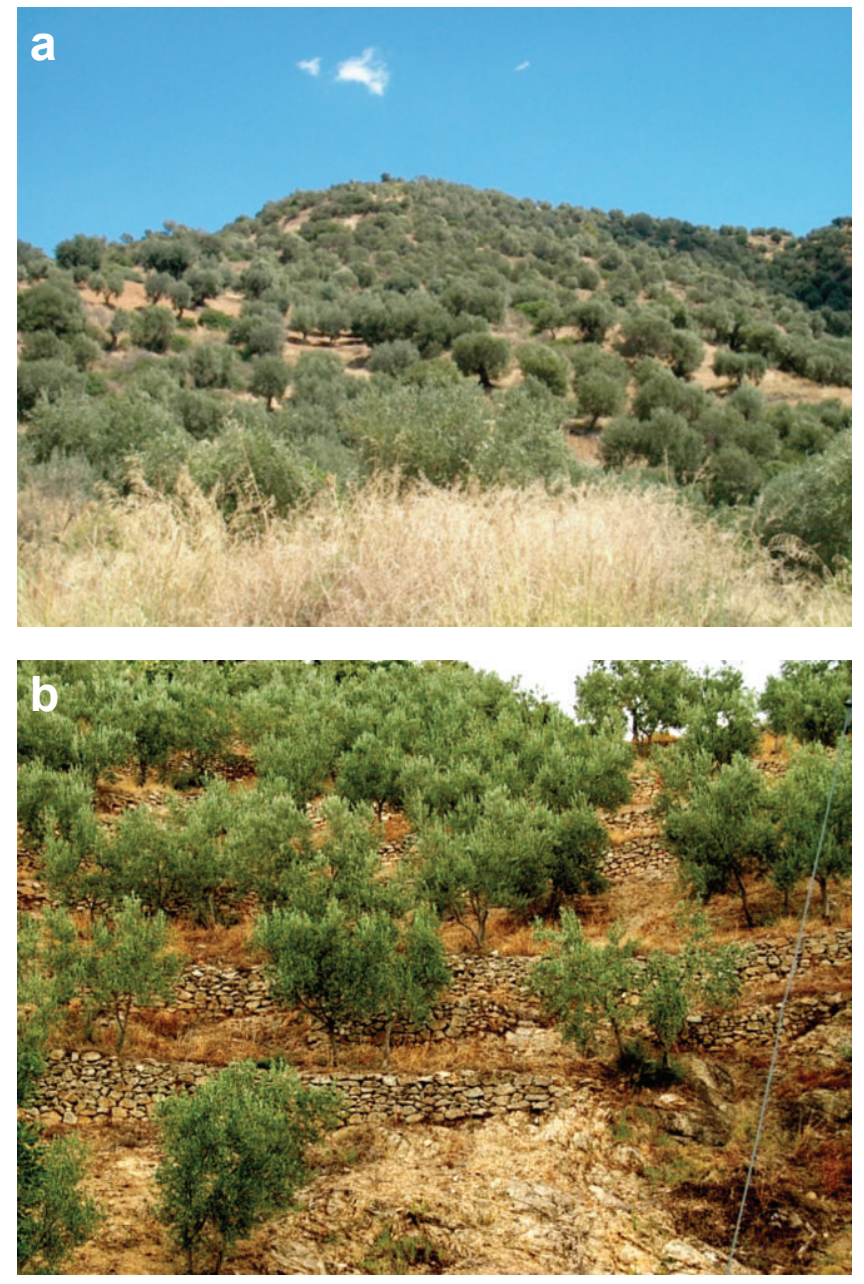

Figure 3. Hilly (a) and terraced (b) marginal olive orchards. 


\section{CAP reforms and oliviculture}

The Common Agricultural Policy in the olive oil sector, has its origins in 1966 (Council Regulation (EEC) n. 136/66) with the establishment of the Common Market Organization (CMO) for oils and vegetable fats, essentially aimed to protect the Italian market, whereas Italy was the only great producer of the that time six European Economic Community (EEC) member States. Basically this Regulation introduced production aid per Mg of oil produced; consumption aid to bottling, buffer stocks and a series of fixed reference prices and duties. After the entry of Greece in 1981 and Spain and Portugal in 1986, a Maximum Guaranteed Quantity equal to $1,350,000 \mathrm{Mg}$ was set to discourage olive oil output exceeds, providing proportional production aid reductions (Figure 5). Anyway, the CMO remained in force, practically unvaried in its settings, until 30 October 1998, albeit with minor modifications over the years. From November 1, 1998 (Council Regulation (EC) n. 1638/9 and 1639/98), so-called reform-bridge was introduced which, although adopted as an ad interim solution (supposed for 3 years), remained in force until the year 2004/05. Even the 1998 CAP reform supported a production aid system which led farmers to systematically increase their outputs with adverse environmental effects, and encouraged fraudulent behaviours with consequent EU's budgetary drifts (Drogué, 2006), so, production limits were set to $1,783,811 \mathrm{Mg}$ per year to help in reducing surpluses, private stocks replaced the common buffer stocks and agri-environment measures (AEM) were introduced. The last CAP reform (Council Regulation (EC) n. 1782/2003), coincided with the mandatory obligations of the principles of cross compliance, under which all compensatory payments given in the context of the former reform packages were replaced by a Single Payment Scheme (SPS), bound to fulfillment of certain requirements and minimum standards regarding the environment and animal welfare, as well as maintaining the land in good agricultural and environmental conditions. As a consequence of this policy reform, olive grove owners are entitled to receive up to $95 \%$ of the subsidies in the base period (around 2250 million euros) as area payment almost entirely decoupled from the kind and/or the level of production (OECD, 2004) with the purpose to avoid distortions in resource allocation. The reference years from 1999/00 to 2002/03- chosen by the European Commission were those which displayed the highest levels of payments and production. Payments were granted where farmers had eligible hectares at their disposal to activate the appropriate number of entitlements, whereas the reference area is the olive surface derived from the olive GIS (GIS hectare) based on an algorithm (OLIAREA) certified by the European Board. According to this methodology about 757 millions olive trees in 5.44 million ha have been estimated in the EU (Masson, 2005).

In April 2004 (Council Regulation (EC) 864/2004 and 865/2004), the olive oil sector was reformed along the lines of the reforms of 2003: a minimum of $60 \%$ of payments was decoupled with a base of 2002-03 to determine the aggregate amount of aid. The reference area was applied only to systems planted before May 1, 1998, and member states might use up to 10 percent of their national olive oil payments to improve the quality of oils. Afterward, Regulation (EC) n. 2012/2006, published in the Official Journal of the European Union n. L 384 of 29 December 2006, changed the foregoing provisions, determining that all surfaces groves are eligible for Single Payment Scheme, therefore, from 2007, entitlements may also be used for new olive groves planted after May 1, 1998, so as to increase the production potential. Although the GAEC includes rules of minimum land maintenance, switching from production-coupled aid to decoupled aid, in general, in the short term, is predicted to lead to intensification being reduced in intensive systems and to production being abandoned in systems where sale revenue does not cover production costs. In the longer term, this could lead to smaller areas and increased concentration of production in areas with comparative advantages (plains that enable the use of machinery and irrigation) (EEIG Agrosynergie, 2009). For the olive oil sector, where potential risks are mainly associated to the abandonment of olive groves, the coupled part of support is aimed to guarantee that the cost of maintenance of olive trees is covered, while the production decision is left to producers (European Commission, 2003). The phenomenon of production abandonment could be particularly common in smaller farms located in marginal areas (De Gennaro, 2006; Saija and Franco, 2008) mostly in mountain zones whose yields are lower and costs of production higher
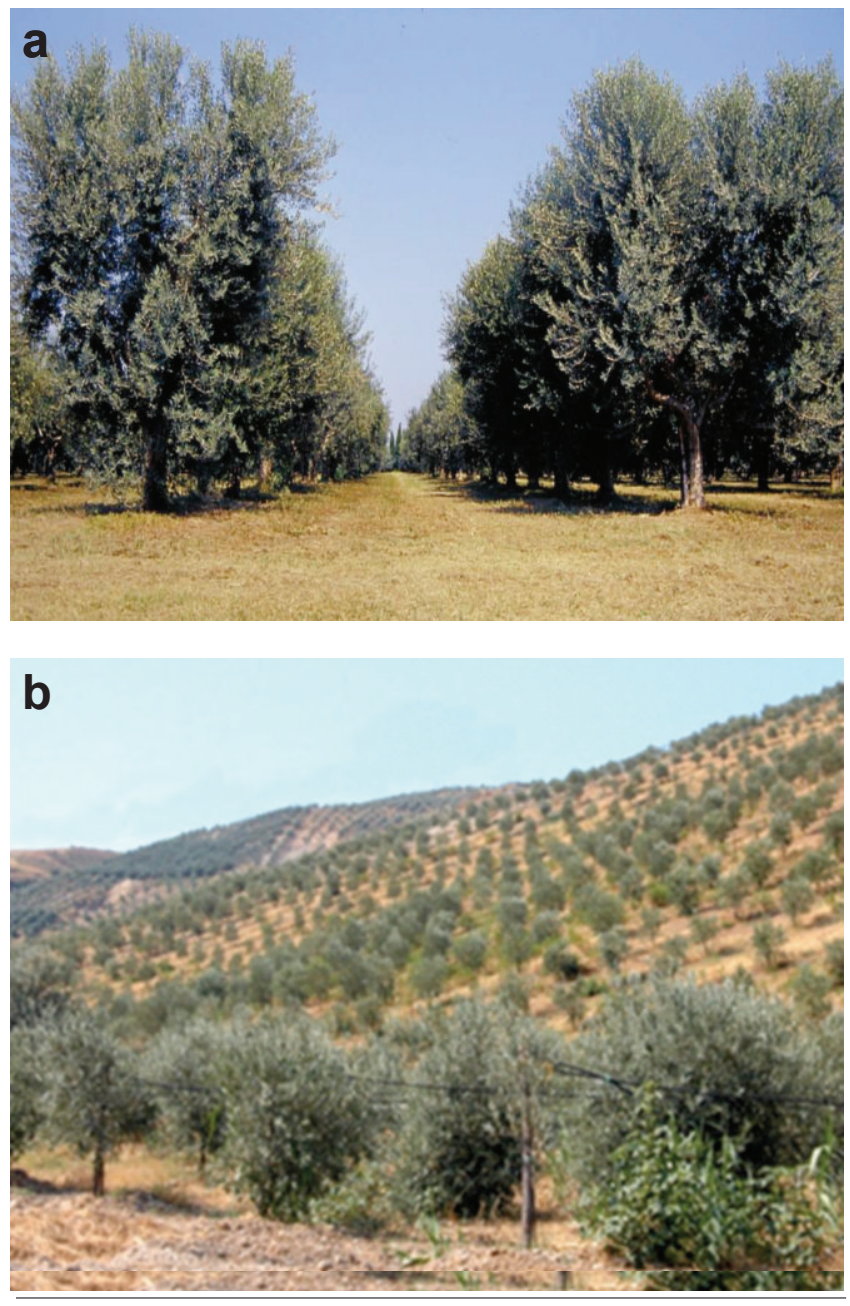

Figure 4. Productive olive groves. Flat (a) and hilly (b) high input traditional olive orchards.

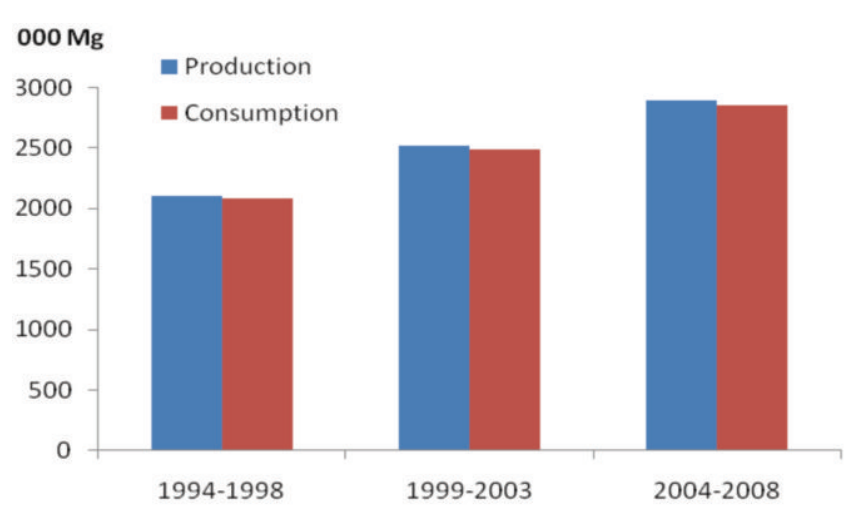

Figure 5. Changes in average world olive oil production and consumption 1994-2008. Source: IOC 
(Arriaza et al., 2008). In this sense de Graaff et al. (2011), developed a linear programming model to assess the various socio-economic and environmental effects of different development scenarios of olive orchards, as a result of changing market prices, wage rates and subsidies, showing that cross compliance obligations may lead to more abandonment and may restrain a move towards more intensive systems as predicted by several olive sector specialists in the respective countries (Fleskens and de Graaff, 2006; Fleskens, 2007). Abandonment of traditional extensive systems would have negative environmental (increased risk of fires and soil erosion), economical (lower local production of olive oil), landscape and socio-cultural (change of traditional groves, depopulation of rural areas) consequences (Beaufoy and Pienkowski, 2000; EEIG Agrosynergie, 2009). This risk is particularly impending in Italy, where, given the limits and constraints of the olive sector, production costs are averagely higher than in other Countries, first of all Spain, where the morphology of the land allows a more modern oliviculture (ISMEA-IPSOA, 2010). Nevertheless, despite the Council Regulation (EC) n. 1698/2005 on support for rural development, which allows agrienvironmental programmes to be designed at national or regional levels according to local farming and environmental traditions, in Italy, the Ministry of Agricultural, Food and Forestry Policies (MiPAAF), Regions and Autonomous Provinces have jointly decided not to use the freedom of autonomy that the EU regulation has left to member Countries, preferring to keep the grant-in-aid system which advantages large landowners. Moreover, considering that -according to the concept of SPS- production decisions tightly depend on market conditions (Mili S., 2006, Katranidis and Kotakou, 2008), the fall in prices of olive oil (Table 2) and in producer income (in EU-27 in $2010-5.7 \%$ as compared to 2009), could be the explanation to the decrease that the sector has shown in the last CAP years (Table 3 and Table 4), in spite of the continuing growth trend in olive oil world consumption (Figure 2). As a result, the Italian oliviculture is costantly losing market share, although it must be underlined how olive growers are orienting their productions to quality, trying to preserve the biodiversity of the territories, as evidenced by the primacy of olive oil trademarks with Protected Designation of Origin, PDO (39 presently, around $40 \%$ of the EU, plus 1 Protected Geographical Indication, PGI), by the increase of organic productions and by the choice to focus, for the most part, on the extra virgin segment (2/3 of the total). PDO/PGI or organic olive oil productions are supported by EC Regulation n. 510/2006, 834/2007 and 73/2009, and even the Regional Development Program (RDP 2007-2013 with agrienvironmental measures (measure 214: integrated and organic production) play an important role in encouraging the implementation of good agricultural and environmental condition.

\section{GAEC in oliviculture}

The Good Agricultural and Environmental Conditions (GAEC) standards were formulated to ensure a minimum level of land maintenance and to avoid the deterioration of habitats.

For olive orchards it's been specifically established the standard 4.3 of the GAEC which concerns the Maintenance of olive groves and vines in good vegetative conditions.

This standard, quite generic, compels farmers: i) to prune olive trees at least every five years; ii) to cut suckers, water sprouts, brambles, weeds and vegetation between rows at least every three years.

Also, according to Annex III, in the National Decree in force, Prohibition of the grubbing up of olive trees (standard 4.5) has been separated from standard 4.3, even if in Italy this rule was already in force in accordance with Law n. 144 February 14, 1951.

The prohibition of the grubbing up of olive trees may generically depend on the age (e.g. >100-year, assigned from farmer declaration, olive cadastre, trunk diameter or trunk sample analysis), on the area (e.g. areas at risk of land abandonment) or on the authorisation needed for such action (Rete Rurale Nazionale, 2010). In Italy, derogations
Table 3. Olive oil prices rise, in $€ / \mathrm{kg}$.

\begin{tabular}{lccccccc} 
Oil & 2005 & 2006 & 2007 & 2008 & 2009 & 2010 & 2011 (trend) \\
Extra virgin & 3.26 & 3.70 & 3.16 & 2.91 & 2.50 & 2.60 & 2.93 \\
Virgin & 2.90 & 3.18 & 2.55 & 2.37 & 2.00 & 1.99 & 2.04 \\
\hline Lamp & 2.66 & 2.78 & 2.17 & 2.10 & 1.75 & 1.59 & 1.49 \\
\hline Source: Ismea. & & & & & & &
\end{tabular}

Table 4. Olive oil production $(000 \mathrm{Mg})$

$\begin{array}{lllllllllll}\text { Yearl } & 2002-03 & 2003-04 & 2004-05 & 2005-06 & 2006-07 & 2007-08 & 2008-09 & 2009-10 & 2010-11 \\ \text { (estimated) }\end{array}$

Source: IOC, FA0 and ISTAT data.

are contemplated for:

- Phytosanitary motives;

- Authorized replanting or uprooting;

- Other cases covered by Law 144/1951 or by specific regional laws and regulations;

- Sites of Community Importance (SCI), Special Protection Areas (SPA) and Sites of Special Scientific Interest (SSSI).

The standard 4.3 was formulated to ensure a minimum level of land maintenance and to avoid the deterioration of habitats through the implementation of cultivation techniques aimed at the care of plants, in order to maintain a balanced vegetative development of the olive grove, in accordance with local types of farming, and prevent the spread of weeds and the risk of fire.

In Italy, each region modified the compliance rules interpretation according to the specific territorial characteristics, in fact, the considerable pedoclimatic variability sometimes has made the norm more restrictive. According to Bazzoffi (2010), the standard is focused more to avoid land abandonment rather than to habitat maintenance. But, considering that the Single Payment Scheme may increase the risk of abandonment, this specific cross compliance rule, could possibly contribute to preventing its negative environmental and social effects.

\section{Erosion, soil management and cover crops}

The preservation of agricultural land has become one of the most contingent problems of agriculture in arid and semi-arid areas, where climatic conditions combined with human accomplishments are causing such levels of erosion that are drastically decreasing the lands productive potential (Figure 6). Erosion is linked to the rate at which water passes into or infiltrates the soil and to the generation of runoff, which is the real culprit of soil loss. In this sense, soil texture, bulk density, slope steepness and slope length (at gradients of 5-10\% erosion starts to appear), organic matter, soil moisture, ground cover, hard pans, surface sealing, rainfall patterns and inadequate farming practices are all factors capable of influencing infiltration and erosion rates (Saavedra Saavedra M., 2007). This phenomenon, reducing the lands biological and productive potential, is behind the destabilization of the ecosystem (Basso et al., 1997) and in extreme cases, can also cause desertification or severe land degradation, with negative effects on human health, natural ecosystems and climate change, as well as on economy.

The problem is particularly serious and contingent in olive orchards, since the occupied areas are commonly marginal and with steep slopes (Aguilar Torres et al., 1996), especially in Italy, where, according to the indications given in Table 1, most part of the national oliviculture is located in hilly zones with a more or less accentuated steepness and is 
traditionally managed with repeated mechanical tillage practices to controlling weeds which are important causes of the establishment of erosion. There are various reports concerning the influence of soil management on soil erosion in olive orchards in different Mediterranean areas (Pastor and Castro, 1995; Kosmas et al., 1997; Raglione et al., 1999; Francia et al., 2000; Pastor et al., 2001; Martínez et al., 2002). According to several authors, in areas characterized by low tree density, controlling weeds by frequent tillage and limiting tree size by pruning, the olive production has been associated with severe soil erosion (Lopez-Cuervo, 1990; Beaufoy, 2001). At the same time, soil erosion results to be one of the most serious environmental impacts associated with intensive olive trees cultivation. However even if the results can be quite contradictory, due to the diverse set of environmental conditions considered, the validity of the spontaneous and permanent cover crop techniques in steep areas has been widely and unanimously demonstrated to reduce erosion, improve water regime and facilitate the infiltration of rainwater (Bozzo and Parente, 1992; Colugnati, 1993; Toscano, 2000; Romero et al., 2007) also because it is well known that excessive tillage, resulting in soil loss, adversely affects the indicators of soil stability such as microbial and fungal diversity, organic carbon content and water stable macro-aggregates (Gómez et al., 2004; Álvarez et al., 2007). Furthermore, permanent
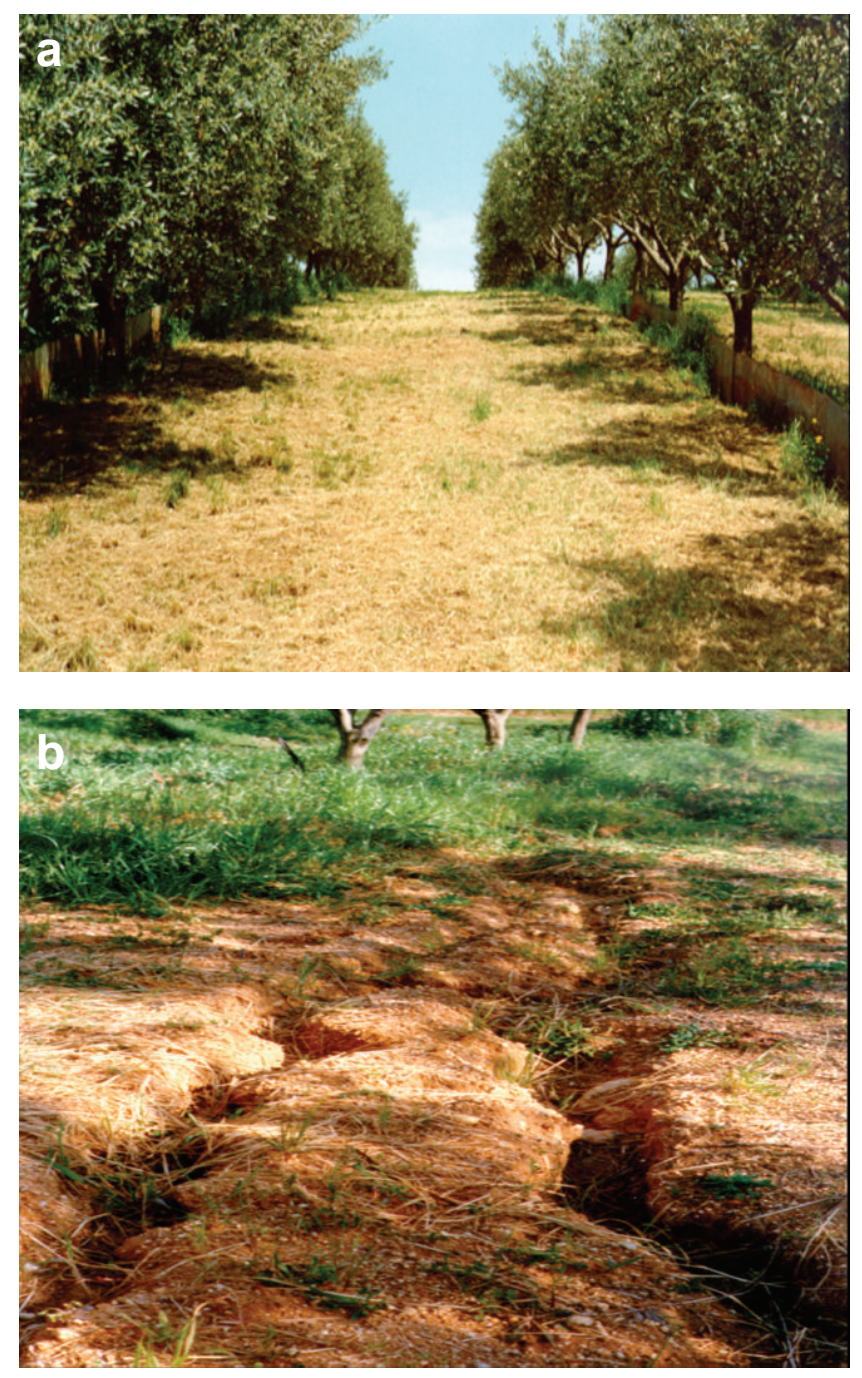

Figure 6. Management effects on soil erosion at CRA-OLI's Az. Li Rocchi - Rende (CS). Soil erosion is much more limited in cover cropped (a) than in tilled (b) soils. cover cropping, facilitates root development and stimulates microorganisms' activity (Kladivko, 2001), with all the associated positive effects on soil fertility and plant productivity.

The presence of vegetation over the entire surface, compared to tilled soil, in sloped hilly olive groves, decreased both the frequency of rainfall events generating runoff (14.7\% vs $38.2 \%)$ and the volume of runoff (10.2 vs $44.0 \mathrm{~m}^{3} \mathrm{ha}^{-1}$ ), with fertile soil removal of 23.1 and $2191.5 \mathrm{~kg}$ ha-1 respectively (Toscano et al., 1999). Raglione et al. (1999), in Southern Italy, measured total soil losses equivalent to 0.36 and $41 \mathrm{Mg} \mathrm{ha}^{-1}$ year-1 under cover crops (CC) and conservation tillage (CT) system, respectively, in a 2-year plot experiment. This trend was further highlighted in the trial prosecution, by the stabilization of the sod, by the entity of turbid waters runoff $\left(99.8 \div 140.3 \mathrm{~m}^{3} \mathrm{ha}^{-1}\right.$, nontilled, vs $416.7 \div 1573.8 \mathrm{~m}^{3} \mathrm{ha}^{-1}$, tilled) and by the quantities of removed soil (2.01 t ha-1 vs $267.43 \mathrm{t} \mathrm{ha}^{-1}$ ) (Toscano et al., 2004).

Supporting these findings, Francia et al. (2006), in a 2-year study in Andalusia, Spain, measured soil losses of 25.6, 2.1 and 5.7 $\mathrm{Mg} \mathrm{ha}^{-1}$ in no-tillage, cover crops and conservation tillage systems, respectively. In Syria, Bruggeman et al. (2005) measured average soil losses of 41.4 and 11.2 $\mathrm{Mg} \mathrm{ha}^{-1}$ year-1 in olive orchards under CT and CC, respectively, in an area with a slope of $24 \%$ for a 4 -year period. Moreover, in olive groves the change from tillage to soil cover management, rapidly diminishes the rate of erosion (Rodríguez-Lizana et al., 2008; Gómez et al., 2009). So, if cover crops appear to be the most effective method for erosion control (Gómez et al., 2003), according to Gómez et al. (2002) the use of cover crops in strips seems to be the most effective method to limit runoff in olive orchards; anyway, it is clear the need for alternatives to conventional tillage management.

Repeated tillages for weed control are also cause of significant organic matter (OM) reduction. Toscano et al. (1999) observed that OM content in cover cropped soils raised up to $122 \%$ compared to tilled ones. The corresponding loss of $0 \mathrm{M}$ amounted to $140.6 \mathrm{~kg} \mathrm{ha}^{-1}$ in crop covered soils vs $5037.4 \mathrm{~kg} \mathrm{ha}^{-1}$ in tilled ones (Toscano et al., 2004). Furthermore, cover crops, contrary to what was assumed by Alvarez et al. (2007), don't imply a risk of yield reduction, in fact, several studies in Andalusia (Pastor, 1990; Castro Nieto, 2004) showed that it may be possible to have vegetative cover without suffering a loss of production if adequately controlled.

In Italy, in a 2-year experiment, the olive yield per plant was on average significantly higher in the permanent cover cropped plot $(10.2 \mathrm{~kg}$ plant $^{-1}$ vs $6 \mathrm{~kg}_{\text {plant }}{ }^{-1}$ ) (Raglione et al., 1999), while, according to Toscano et al. (2004), in the same experimental plot, after 5 years it was averagely $13.59 \mathrm{~kg}$ (cover cropped plot) vs $10.73 \mathrm{~kg}$ (tilled plot). In a trial conducted in Italy for a 7 -year period in an olive orchard growing in a semi-arid environment, it was shown that trees managed under the sustainable model (with spontaneous cover crop) produced almost constantly every year, with an average yield of $8.4 \mathrm{Mg} \mathrm{ha}^{-1}$ year-1 (20012006 period), while plants traditionally managed (with periodic tillage) showed a lower level of production ( $3.1 \mathrm{Mg} \mathrm{ha}^{-1}$ year $\left.{ }^{-1}\right)$ and a strong yield alternance with little or no production in 2002, 2004 and 2006 (Sofo et al., 2009).

In the olive groves of the plains, the temporary cover crops adoption with green manure application in late spring, instead, resulted more effective on the evolution of soil characteristics and on plants productivity compared to permanent cover crop. The results from four years of observations with this type of land management showed a larger increase of $\mathrm{OM}$ in the plot with temporary cover cropping (+40\%) than in the one with permanent cover cropping (+ $32 \%)$ (Toscano et al., 2006). Moreover, properly grinded crop and pruning debris should be left on the soil's surface (Figure 7) to increase the olive groves OM content (Palese et al., 2009; Neri et al., 2010).

Always along this line the use of compost, deriving from olive pruning and mill residue biomass, can also represent an opportunity to 
recover the organic soil fertility and to dispose wastes in an environmentally friendly manner (Delfine et al., 2009), in fact a recent experimental work on the assessment of the compost's nutritional and fertilizer effectiveness, has described increases up to $62 \%$ of $0 \mathrm{M}$ in composted soils (Toscano et al., 2008).
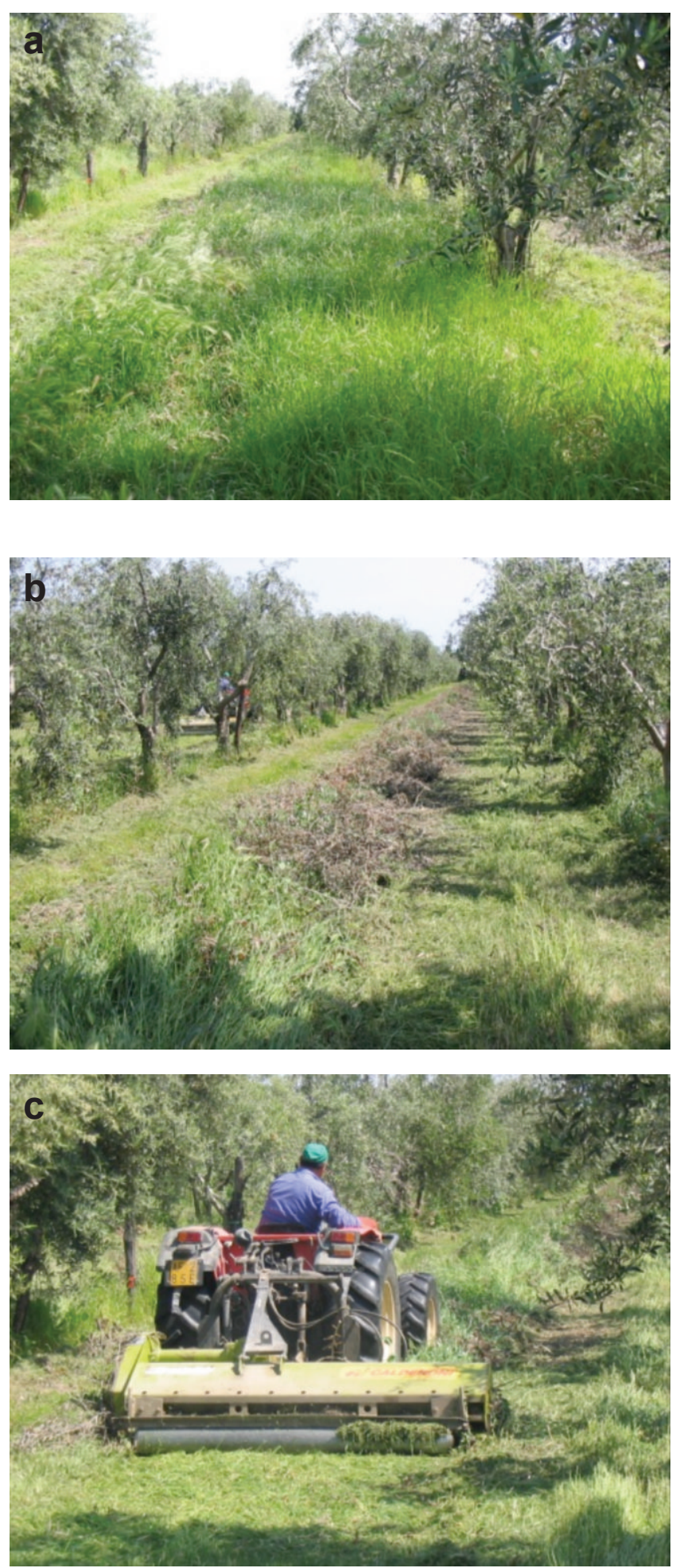

Figure 7. Mulching the soil with grinded weeds and pruning debris. Passage of a mulcher (c) grinding weeds (a) and pruning debris (b) to increase organic matter content in the soil.

\section{Olive trees pruning and good vegetative conditions}

Pruning is the most common olive tree maintenance procedure to fulfill several purposes, depending on age and plant's vegetative stage, being essential to shape young trees in the first years of implant and thereafter to check the equilibrium conditions between vegetative and productive activity. In the diverse Italian realities of the olive sector, this technique is applied at different times and in ways depending on the specific objectives of individual growers. From a productive point of view, pruning should be carried out every year so as to be less intense, adopting all the most modern methods to make it as quick and economical as possible. Annual pruning allows regulating at best the balance between vegetative and reproductive activities and so contributes to reduce alternate bearing. Anyway biennial or even longer pruning turns give different results depending on olive variety.

In the north-central Italian regions, pruning takes place in most cases every year, while longer shifts are generally carried out in southern Italy because of the high costs required from this operation. In fact, olive trees in the South can reach considerable dimensions given the optimal conditions for vegetative growth of this species (Figure 8).

Numerous papers, published in Italy and abroad, demonstrate that productivity and oil yield are not reduced (in some cases even increased, albeit slightly) after biennial instead of annual pruning.
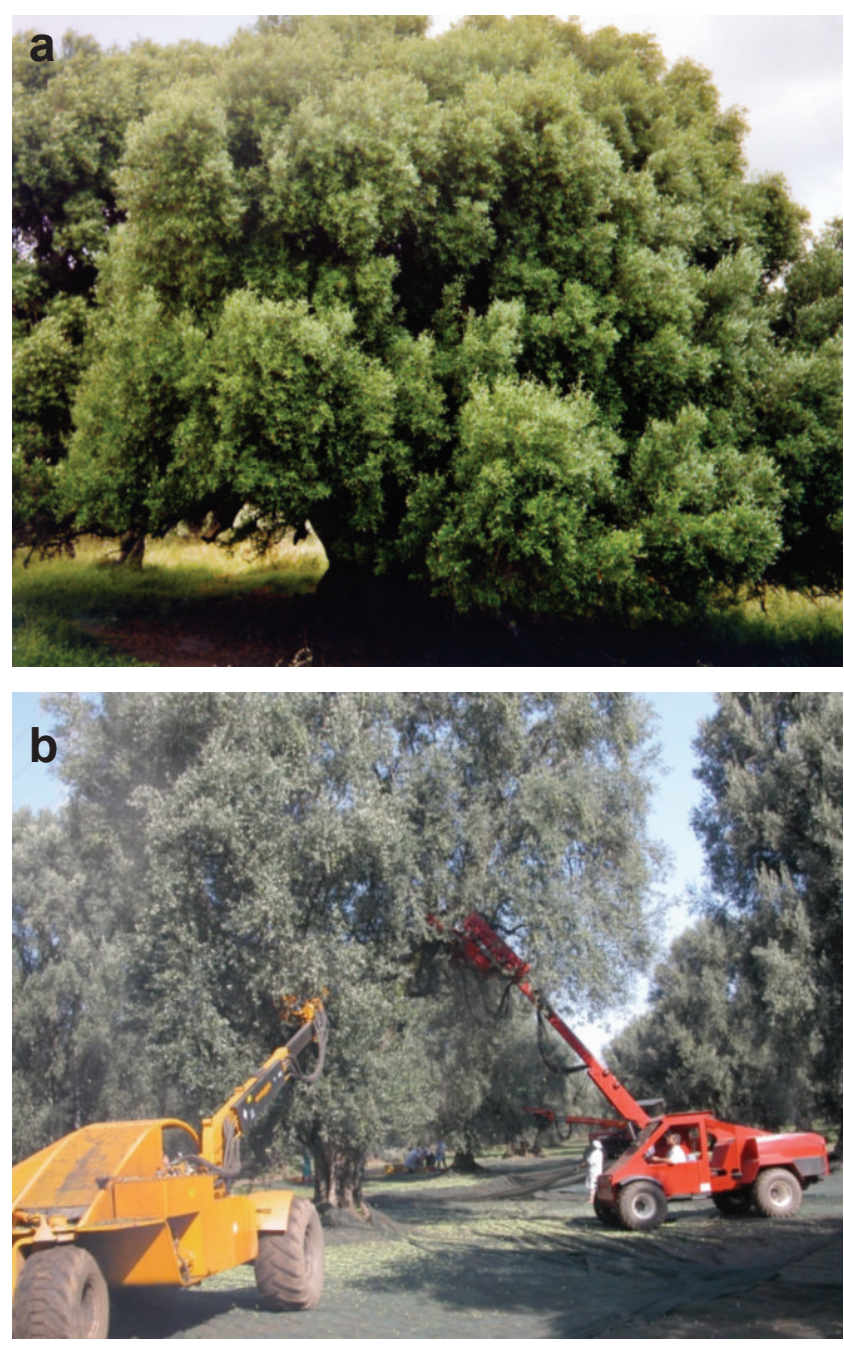

Figure 8. Majestic olive groves in South Italy. Secular (a) and majestic olive trees require particular and expensive pruning practices (b). 
According to Pannelli (2006) the evolution of this technique in Central Italy showed that annual pruning results to be the most rational, positively influencing the fruiting constancy and requiring overall less working time. Biennial and triennial cycles have proved attractive to recover the plants' productive potential and to reduce costs as less detailed and specific operations. However, longer intervals (3-4-6 years) between prunings, cause shading and irrational spatial distribution of the canopy. Additionally the consequent poor lighting condition causes short and compact outward vegetation and deadwoods in the inner part of the crown that will result in overall low productivity (Tombesi et al., 2002). From a two-year monitoring of pruning influence on nutritional and productive status of ultra centenarian plants (pruned every 6 years), a significantly higher increase in the number of nodes in pruned plants was observed compared to non-pruned ones (average 341.21 vs 134.05). On the contrary, the highest production was recorded (one year data due to alternate bearing) in non-pruned plants (147.75 vs $53.65 \mathrm{~kg}$ per plant). The lower production was a consequence of pruning intensity that, being practiced every six years, led to a drastic reduction in fruitful branches (Briccoli Bati et al., 1995). Morales (2002) reported that in a traditional olive grove, pruning periodicity (every two or four years) effectively affects the spatial canopy volume achieving $+11.62 \%$ if performed every two years and $+31.21 \%$ with four years cycles. Therefore, the author concludes that olive plant better maintains its balance with three- and four-year pruning programs as productions increase.

By contrast, pluriennial pruning cycles, being necessarily more intense, stimulate the formation of abundant water sprouts and suckers (very vigorous branches arising respectively from the aerial part and from the foot of the tree), which are indicative of high vegetative activity and vegeto-productive imbalance. It is fundamental to annually cut off suckers and water sprouts for assuring a normal vegetative and productive growth, because they attract most of the nutrients which so can't be assimilated by the plant itself (Figure 9). Too deferred pruning cycles are also negative causing deadwood and wood excesses on the entire plant, poor ventilation and lighting in the inner part of canopy, lack of photosynthesis and harvesting difficulties; moreover they make the plants more susceptible to pests attack (Figure 10). Another aspect to consider is the destination of the resulting pruning material. In olive groves, these residues are usually burned on-site. This practice may cause damages to trees, and multiplies wildfire risk (Rodríguez-Lizana et al., 2008) and leads to the formation of Polycyclic Aromatic Hydrocarbons (PAHs) that can be absorbed by fruits and consequently found in oil because of their high lipophilicity. Pruned material, if grinded and left in situ, can afford large amounts of organic carbon that is fixed for a long time in the form of humic substances, increasing the total soil fertility and strengthening the atmospheric $\mathrm{CO}_{2}$ sequestration capacity of the whole olive grove system. The importance of pruning debris management has been highlighted also from a green point of view. In fact, in a 2005 study, Palese et al. (2005) stated that the amount of $\mathrm{CO}_{2}$ fixed in the removed vegetation varies from $0.21 \mathrm{~kg} \mathrm{plant}^{-1}$ to $6.52 \mathrm{~kg}$ plant $^{-1}$, equivalent respectively to 0.11 and $3.62 \mathrm{Mg} \mathrm{ha}^{-1}$.

\section{Biodiversity in olive grove}

The definition of biodiversity should not be restricted solely to the issue of genetic resources or the conservation of threatened species. As specified by the Convention on the Biological Diversity and the PanEuropean Biological and Landscape Diversity Strategy, biodiversity is the variety of life and its processes. It includes all life forms, pathways and cycles that link living organisms into populations, ecosystems and landscapes. The new CAP rules, intrinsically linking biodiversity and agriculture, put the focus on the maintenance of natural habitats such as hedgerows and forest patches, protecting in the meanwhile flora and fauna with particular reference to birds.

The biodiversity of a landscape is closely related to the quality of a

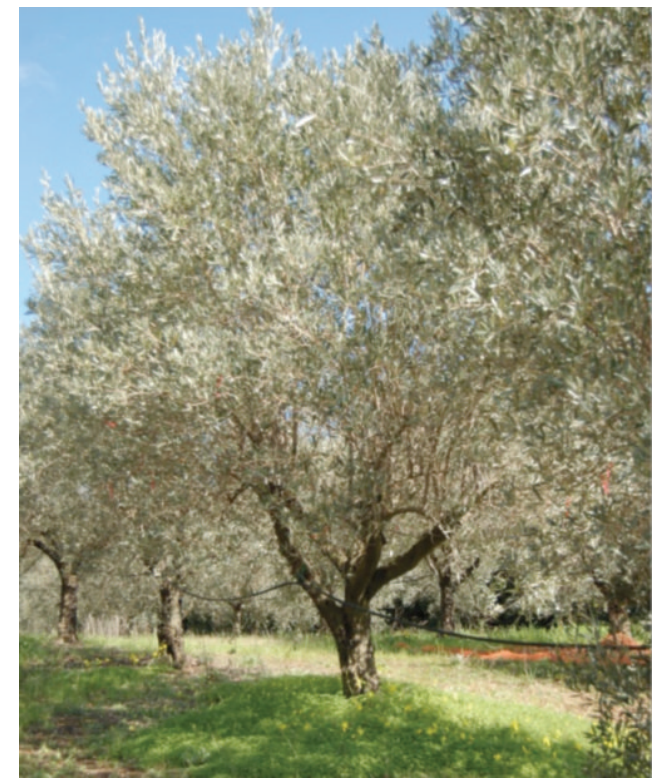

b

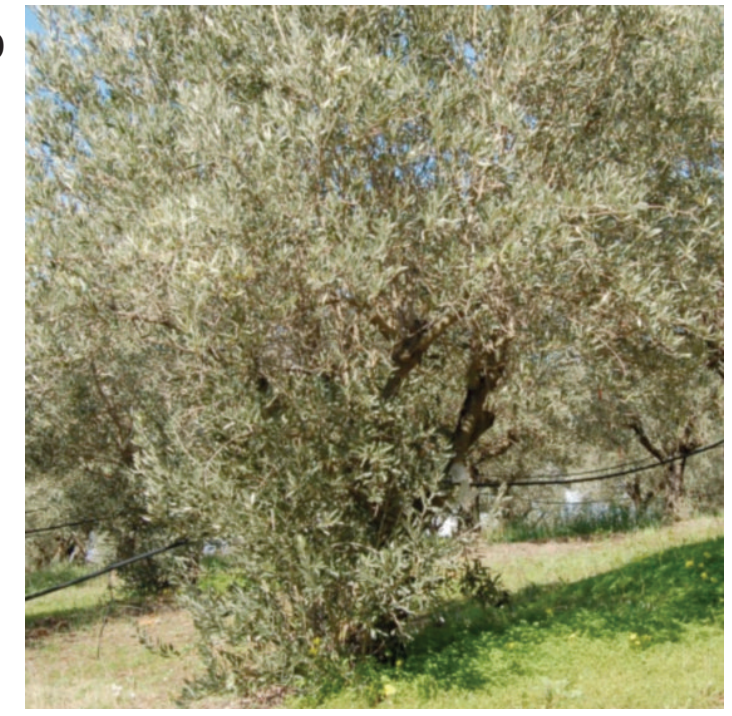

C

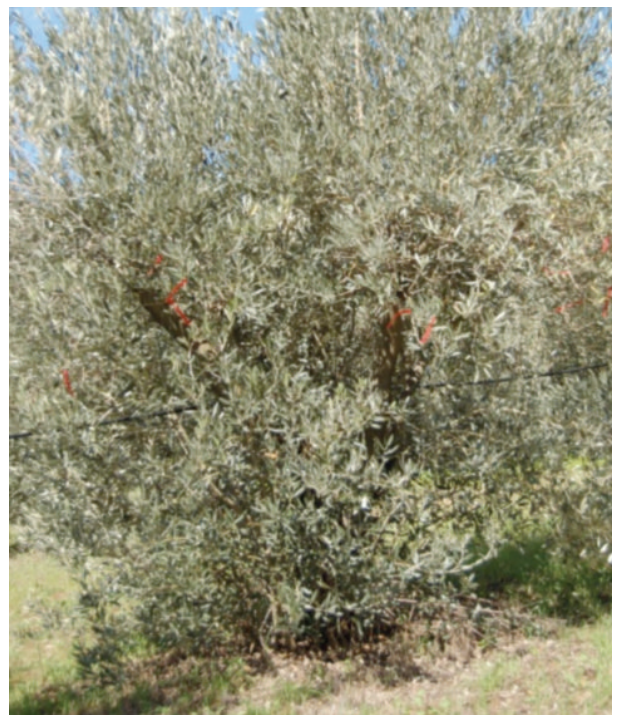

Figure 9. Effects of cutting water sprouts on olive trees vegetative growth. Cutting water sprouts every one (a), two (b) or three (c) years involves a different and unbalanced vegetative and productive plant growth. 
each habitat, the diversity of habitats, their turnover and the spatial relationships among them (Firbank, 2008). A complex mosaic of habitats in the agro-ecosystem play an important role along with natural areas since it hosts many plants and animal species of great interest for conservation purposes in contrast with modern management of landscape, generally supporting lower number of plants and animals (Barbera et al., 2005).

There are numerous mechanisms of biodiversity loss and extinctions, including: habitat loss or fragmentation, deforestation, agricultural practices, pollution, over exploitation, introduction of alien and invasive species, and climate change (Cincotta et al., 2000; Sala et al., 2000; Hodgson et al., 2005; Lewis, 2006). Allen et al. (2006), argue that environmental variables explain about $60 \%$ of the species-environment relationships, the remaining variation in species composition is interpreted to be the result of different cultivation practices. So, high fertilization doses, intensity of cultivation, mechanization, integration or not of livestock production and type of livestock production, short crop rotations or monoculture combined with chemical plant protection management, conversion of natural ecosystems to agriculture as well as the abandonment of farm land, cause depletion of species richness and diversity (McLaughlin and Mineau, 1995).

Olive groves as well as windbreak olive trees (Lo Verde et al., 2002), represent a component of great importance to combine biodiversity conservation with local environmentally sustainable development, since these systems constitute elements of a mosaic of semi-natural and cultivated areas spaced out by typical small-scale structural, show high levels of richness in flora and fauna and play an important role in the rural developments (Santi et al., 2010). The presence of trees and scrubland provides an assorted habitat similar to meadows where a number of insects, birds, reptiles mammals (Gomez-Limon and Risiego, 2010) and associated annual herbaceous vegetation live more or less characteristically as a function of the management system (Paracchini and Britz, 2010). Semi-natural and abandoned vegetation patches or strips can be an important refuge for a lot of polyphagous invertebrate predators (Cotes et al., 2009a) or butterflies (Scalercio et al., 2007). Furthermore the presence of some field boundary types can provide overwitering refuges for many arthropod species in arable field system (Thomas et al., 1991). Even stone terraces, decreasing slope length, diminish surface runoff and favour the infiltration of water, a high bio-diversity and low pollution rates.

However, the ongoing intensification of olive growing (the planting density can vary from 250 plants ha ${ }^{-1}$, traditional extensive, up to 1800 plants $\mathrm{ha}^{-1}$ in super-intensive groves) irrigation, fertilization, insecticide use and suppression of annual herbaceous vegetation by ploughing or herbicide treatments, contributes to soil degradation, water pollution and both the number and the diversity of animal species diminishment (Gómez-Limón and Risiego, 2010; Duarte et al., 2009; GómezCalero, 2009; García-Brenes, 2007; Guzmán-Álvarez, 2005; Beaufoy and Pienkowski, 2000). This is why biodiversity is generally higher in semiabandoned and/or traditionally managed olive groves; in fact they offer a wide variety of habitats (e.g. dry-stone walls patches of natural vegetation, etc.), providing a niche for reptiles, birds and insects (Fleskens, 2008). These no tillage and pesticide free farming systems allow a rich flora and a high diversity and density of insects which, together with the tree's fruits, provide an abundant supply of food for a variety of bird species (Rey 2010; Beaufoy, 2001; Parra, 1990). The relationship between birds and olive trees is of mutual benefit: birds, in fact, represent the most effective disseminators of this tree that is just called bird-dispersed (Alcantara and Rey, 2003). 31 bird species have been located in olive groves (Theodorakakis, 1995; Giourga et al., 1994), both winter (Debussche and Isenmann, 1985; Suarez and Munoz-Cobo, 1984; Jordano and Herrera, 1981; Niethammer, 1966) and nesting or migratory ones (Munoz-Cobo, 1990; Finlayson, 1981). This avifauna, compared to the other agro-systems, is the nearest, in qualitative and
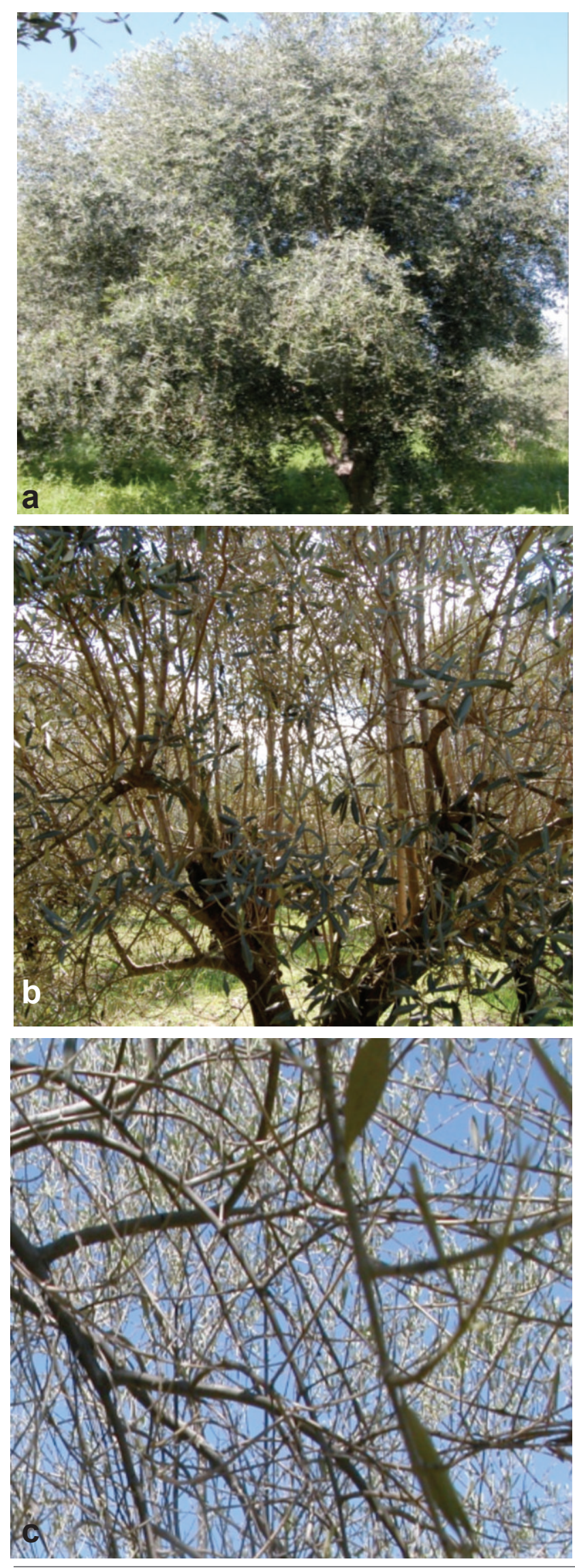

Figure 10. Unpruned olive trees. Deferred pruning cycles cause irrational space distribution of the canopy (a) and the formation of suckers (b) and deadwood (c). 
quantitative terms, to the one found in natural environments (La Mantia, 2002; Massa and La Mantia, 1997).

Some bird species can nest in the hollow and twisted trunks of ageold olive trees (LIFE), some others breed or feed in the vegetation around the bases of trees or between the trees on semi-open ground as many of these features are lost or modified through this process (Pain, 1994). Many other migratory birds are found in cultivated areas where they search for food; the robin (Erithacus rubecula), and the starling (Sturnus vulgaris) are very commonly observed in the olive groves in winter, whereas white and yellow wagtails are frequently sighted near animal farms where they search for insects in the manure heaps (CENT.OLI.MED, 2009).

It's therefore advisable to maintain or restore patches of shrubs or hedges within or near the olive orchard to provide nesting sites for typical birds species of the Mediterranean (Lipu, 2010). The presence of spontaneous vegetation inside the olive agro-ecosystem represents also an important reservoir of entomophagous (Iannotta et al., 2007a). In fact, a rich flora supports alternative prey and hosts for natural enemies, providing useful seasonal resources to overcome gaps between the life cycles of useful entomophagous insect and crops' phytophagous accompanied by a lower presence of arthropod pests (Altieri and Schmidt, 1985; Bugg et al., 1991; Hendricks, 1995; Corrales et al., 2004). The herbaceous cover could play a valuable role in reducing the impact of the compounds used in olive growing against arthropods communities, providing a shield against the direct and prolonged contact with the active ingredients (Iannotta i 2007b). Besides, cover crops affect the biocenotic component of agro-ecosystems increasing the porosity of the soil, and establishing a better telluric air/water rate (Breland, 1995). Therefore it is desirable to maintain the turf, especially in olive groves treated with pesticides, since it increases the resilience of communities (Iannotta et al., 2007b,c).

In general, soil micro-, meso-and macrofauna have a crucial role in the degradation of organic matter, and in the mineralization of nutrients, balancing the availability of nutrients (Gobbi, 2009) also they can act as agents of biological control of the olive pests that spend a period of their life cycle in the soil (Herrick, 2000) just like ants which are the most numerous predators observed of the olive fruit fly (Bactrocera oleae) pupates in less disturbed olive grove floor and, reliably, they can be a tool in control olive fruit fly. Moreover, they are important environmental quality indicators, capable to react to, even mild, perturbations (Young et al., 1998; Santos et al., 2007; Latella and Gobbi, 2008). Recently Parisi et al. (2001; 2005) proposed a new approach (called QBS index) based on the types of edaphic micro-arthropods to assess soil biological quality. In general, soil invertebrate-based indices consider the consistency and richness of populations (see van Straalen, 1998; Jacomini et al., 2000), the QBS index is based on micro-arthropod groups present in a soil sample where each of them in the sample is scored (eco-morphological index, EMI), according to its adaptation to soil environment. The QBS index sums up these scores, thereby characterizing the micro-arthropod community of the sample. The classification of soil fauna into morphologic-functional groups can contribute to the assessment of impacts of agronomic practises on the biota. Biological activity and microbial diversity are higher in undisturbed soils and/or soils managed according to modern techniques of conservative agriculture compared to soils subjected to intensive tillage (Nsabimana et al., 2004). Kladivko (2001) noted that the most common species of terrestrial fauna are even the most vulnerable to tillage, while a minimum mechanical soil disturbance, when combined with rational management of crop residues, increases the number of populations of earthworms (Kladivko, 2001; House and Parmelee, 1985). Soil tillage in the olive grove has a high impact on arthropod walkers since it involves plant diversity reduction and loss of habitat, ecological niches, particular micro-climatic conditions and shelter areas from predators (Iannotta et al., 2006). Arthropods are useful indicators in assessing the environmental changes caused by pesticides applications in agricultural environments (Iannotta et al., 2007d). An additional parameter which can provide information on the ecological characteristics of the ecosystem is the carabid beetles community that responds by changing its power of dispersion and degree of food specialization (Pizzolotto et al., 2008). From a global examination of the carabidofauna, none of the ecological characteristics studied seem to be influenced in a decisive manner by synthetic or organic pesticides treatments. A greater impact is certainly attributable to mechanical soil processing that changes the community structure reducing it and eliminating the small differences caused by treatments. A marked increase in diversity and equidistribution is observed in bio-natural olive groves, where anthropic impact is almost zero (Antonucci, 2007; Belfiore, 2008). The most common sampling procedure used to study epiedaphic fauna is by technique of pitfall trapping. Studies conducted in olive grove with this methodology in Spain (Morris and Campos, 1999) and Portugal (Santos et al., 2007) showed that the most abundant epigeic taxa of soil fauna are Formicidae and Coleoptera. In these studies the presence of other groups can vary and depends on the localisation of the olive grove, the management and the surrounding vegetation.

Redolfi et al. (2004) state that the disturbance caused by cultivation practices affects the density and abundance of ants nests in the soil under plants and between rows. Ruano et al. (2004) provided information concerning appropriate sampling location (canopy, the soil under the trees, solarised soil) in olive orchards by means of analysis of changes of arthropodo-fauna in relation to different management regimes (organic, integrated and conventional). The highest abundance of arthropods occurred in the integrated management orchard and the most abundant groups were Formicidae and the species Euphyllura olivinae (Homoptera: Psyllidae) as a result of less influence of chemical treatments. The Authors also suggested that in the aerial part of olive tree, Coleoptera, Diptera, Heteroptera, Lepidoptera and Thysanoptera communities can be considered as potential biomarkers of different management practices, especially Coleoptera and Lepidoptera; whereas Coleoptera are normally reduced by the mechanical soil operations (Wardle, 1995).

In olive groves with different management systems (organic, integrated and conventional) spider abundance was significantly higher on organic orchards than conventional ones. An intermediate level of disturbance resulting from the integrated conduction increases spiders diversity, while in conventional cultivations, the dominance of one family species is favored (Wardle, 1995; Cardenas et al., 2006). Nevertheless several authors suggested that ants, carabid and staphylinid beetles, as well as spiders and Lepidoptera (Redolfi et al,. 1999; Scalercio, 2006; Cárdenas et al., 2006; Belfiore et al., 2006; Scalercio et al,. 2007; Iannotta et al., 2008; Cotes et al., 2009a) or parasitoid wasps, specialised aphidophaga among the syrphid flies, coccinellids and Neuroptera (Duelli and Obrist, 2003; Corrales and Campos, 2004; Cotes et alet al., 2009b) are potentially important natural pest-control agents. Other possibilities for indicators to be tested are ratios between herbivores and predators, or parasitoids and a range of other arthropods (Denys and Tscharntke, 2002). In a study realized by Sofo and collaborators (2009), the different soil treatments (sustainable tillage -ST- vs. conventional tillage -CT-) significantly affected both total culturable bacteria (fewer numbers in ST), and fungi total number (lower in CT). Their results showed that soil microorganisms respond to the sustainable management of the olive grove, with obvious benefits on fruit quality and oil yield. The sustainable management displayed a higher microbial diversity and complexity. The study of the soil microbiota response to different management systems and the quantitative and qualitative analysis of soil microbial communities could lead to identify farming practices sustaining and stimulating soil microorganisms, in order to improve the orchard production and restore, or at least maintain, soil fertility. 


\section{Conclusions}

The study evidenced that a rational olive grove management is the first step to prevent further soil fertility deterioration. Proper hydraulicagricultural techniques, cover cropping, green manuring and $\mathrm{OM}$ increase -by spreading grinded pruning residues and/or by incorporating organic amendments-, are essential not only to minimize losses due to soil erosion but also to limit the leaching of nutrients and to maintain the productivity of plants. These environmentally friendly land management techniques improve the olive vegeto-productive balance and contribute, also, to immobilize $\mathrm{CO} 2$ in the soil as humic substances, thus increasing the $0 \mathrm{M}$.

The application of the standard 4.3 requires further investigations, because, while numerous studies have shown that pruning is essential for the production, there are not enough data on the influence that practicing this technique at least every five years could have on habitats maintenance and on olive trees vegetative development. In fact, shorter or longer pruning cycles should be performed depending on climatic characteristics, on achieved productivity and, especially, on fruiting branches growth. In particular, for a sustainable plant management, cutting water sprouts and mowing weeds and shrubs should be performed at least once a year to reduce the risk of fire. In productive facilities it's a common practice to prune every two or three years and to cut suckers and watersprouts annually for constantly keeping the vegeto-productive balance of the plants.

In line with the examined literature this standard seems to be too generic and should be diversified according to different types of olive orchards. Unproductive, marginal and abandoned olive groves, require special attention as they allow landscape and biodiversity preservation, as contemplated by the priority strategic objectives set out by the European Union (European Council, Göteborg 2001). Their operating costs, not offset by the production, require more focused interventions, even to avoid the always more incumbent abandonment risk. The standard should, also, specify how to handle the pruning residues for their importance in the atmospheric CO2 sequestration and soil OM increase, and provide the annual elimination of weeds and suckers, in order to prevent the wildfire risk and nutrients competition.

Anyway, this norm appears to be effective if framed in a wider and more articulated context whose aim is to encourage farmers to introduce or continue the use of agricultural production methods compatible with environment, and genetic diversity protection and improvement.

\section{References}

Aguilar Torres F.J., Gonzàlez Fernàndez P., Pastor Munoz-Cobo M., 1996. Miglioramenti della fertilità del terreno dell'oliveto con l'applicazione periodica di compost di residui solidi urbani. Confronto con il sistema di non lavorazione con suolo nudo. Olivae 64:40-45.

Alcantara J.M., Rey P.J., 2003. Conflicting selection pressures on seed size: evolutionary ecology of fruit size in a bird-dispersed tree, Olea europea. J. Evol. Biol. 16:1168-1176.

Allen H.D., Randall R.E., Amable G.S., Devereux B.J, 2006. The impact of changing olive cultivation practices on the ground flora of olive groves in the Messara and Psiloritis regions, Crete, Greece. Land Degrad. Develop. 17:249-273.

Altieri M.A., Schmidt L.L., 1985. Cover crop manipulation in northern California apple orchards and vineyards: Effects on arthropod communities. Biol. Agric. Hortic. 3:1-24.

Álvarez S, Soriano M.A., Landa B.B., Gómez J.A., 2007. Soil properties in organic olive groves compared with that in natural areas in a mountainous landscape in southern Spain. Soil Use Manage. 23:404-416.

Antonucci C., 2007. Le Comunità dei Coleotteri Carabidi nell'agroecosistema oliveto. Degree Diss., Calabria University, Cosenza, Italy.

Arriaza M., Gómez-Limón J.A., Kallas Z., Nekhay 0., 2008. Demand for non-commodity outputs from mountain olive groves. Agricultural Economics Review 9:5-23.

Barbera G., Inglese P., La Mantia T., 2005. La tutela e la valorizzazione del paesaggio dei sistemi tradizionali dell'olivo in Italia. Estimo e Territorio, Anno LXVIII, n. 2, Il Sole24ore, Ed agricole.

Basso F., Pisante M., De Franchi A.S., Bassi P., 1997. La difesa dai fenomeni erosivi nell'Italia Meridionale. Inform. Agr. 43:33-37.

Bazzoffi P., 2010. Environmental Effectiveness of GAEC Standards. Report on Cross Compliance implementation in Italy. GAEC Workshop, Roma, Italy. Available from: www.reterurale.it

Beaufoy G., Pienkowski M., 2000. The environmental impact of olive oil production in the European Union: practical options for improving the environmental impact. European Forum on Nature Conservation and Pastoralism, Brussels, Belgium. Available from: http://ec.europa.eu/environment/agriculture/pdf/oliveoil.pdf

Beaufoy, G., 2001. EU Policies for Olive Farming. Unsustainable on all Counts. WWF and Birdlife International, Brussels, Belgium. Available from: http://www.wwf.org.uk/ filelibrary/pdf/oliveoil.pdf

Belfiore, T., 2008. Impatto sulla artropodofauna di prodotti ammessi contro la Bactrocera oleae (Rossi, 1790) in olivicoltura biologica. Degree Diss., Calabria University, Cosenza, Italy.

Belfiore T., Brandmayr P., Scalercio S., Condello L., Iannotta N., 2006. Diversità ed entità dell'entomocenosi in oliveto trattato e naturale. Italus Hortus 13:173-176.

Bozzo F., Parente G., 1992. Valutazione di diverse specie per l'inerbimento artificiale del vigneto. Inf. Agrario 11:117-121.

Breland T.A., 1995. Green manuring with clover and ryegrass catch crops under sown in spring wheat effects on soil structure. Soil Use Manage. 11:163-167.

Briccoli Bati, C., Tocci, C., Turco, D., 1995. Influenza di differenti volumi, turni e modalità di distribuzione dell'acqua su un giovane oliveto. pp 327-333 in: Atti Convegno Tecniche, Norme e Qualità in Olivicoltura, 15-17 Dicembre 1993, Potenza, Italy.

Bruggeman A., Masri Z., Turkelboom F., 2005. Strategies to sustain productivity of olive groves on steep slopes in the northwest of the Syrian Arab Republic In: J. Benites, M. Pisante and F. Stagnari (eds.) Integrated Soil and Water Management for Orchard Development; Role and Importance. FAO Land and Water Bulletin, Roma, Italy, 10:75-87.

Bugg R.L., Anderson J.H., Menke J.W., Crompton K., Lanini W.T., 1991. Perennial grasses as roadside cover crops to reduce agricultural weeds. Components 2:14-16.

Cárdenas M., Ruano F., Garcia P., Pascual F., Campo, M., 2006. Impact of agricultural management on spider populations in the canopy of olive trees. Biol. Control 38:188-195.

Castro Nieto G., 2004. La cubierta vegetal en el olivar: determinación experimental del uso de agua y de su influencia sobre los procesos de infiltración, escorrentía y erosión. Trabajo Profesional Fin de Carrera, University of Córdoba, Spain.

CENT.OLI.MED Project, 2009. Ancient Olives Groves. Available from: www.lifecentolimed.iamb.it/index.php?option=com_content\&view $=$ article\&id=23\&Itemid $=50 \& l a n g=e n$

Cincotta R.P., Wisnewski J., Engelman R., 2000. Human population in the biodiversity hotspots. Nature 404:990-992.

Corrales N., Campos M., 2004. Populations, longevity, mortality and fecundity of Chrysoperla carnea (Neuroptera, Chrysopidae) from olive-orchards with different agricultural management systems. Chemosphere, 57 (11):1613-19.

Colugnati, G., 1993. Ipotesi praticabili nella gestione dell'inerbimento 
del vigneto. Inform. Agr. 42:65-67.

Cotes B., Castro J., Cardenas M., Campos M., 2009a. Responses of epigeal beetles to the removal of weed cover crops in organic olive orchards. Bull. Insectology 62:47-52.

Cotes B., Ruano F., García P. A., Pascual F., Campos M., 2009b. Coccinellid morphospecies as an alternative method for differentiating management regimes in olive orchards. Ecol. Indic. 9:548555.

De Gennaro B., 2006. La riforma dell'OCM olio d'oliva: contenuti e impatto sul settore olivicolo. Università degli Studi di Bari, Italy. Available from:

www.unaprol.it/news/metes/de\%20Gennaro.pdf

Delfine S., D'Imperio M., Marcellino G., 2009. Gestione Agronomica dell'Oliveto: Effetto dell'Utilizzo di Compost su Accrescimento, Ecofisiologia e Produzione. pp 113-114 in: M. Bindi (ed.), Atti XXXVIII Convegno SIA Tecniche agronomiche, Produzioni vegetali, Ago-ambiente, Qualità dei prodotti, Firenze, Italy.

Debussche M., Isenmann P., 1985. Le regime alimentaire de la Grive musicienne (Turdus philornelos) en automne et en hiver dans les Garrigues de Montpellier (France Mediterraneenne) et ses relations avec l'omithochorie. Terre et Vie 40:379-387.

Denys C., Tscharntke T., 2002. Plant-insect communities and predator-prey ratios in field margin strips, adjacent crop fields, and fallows. Oecologia 130:315-324.

Drogué S., 2006. The EU olive oil policy, recent evolutions and perspectives. Cahiers de Recherche 2006/01 Thiverval-Grignon, INRA Publ., Paris, France.

Duarte F., Jones N., Lúcio C., Nunes, A., 2006. The reform of the olive oil regime and its impacts on the olive and olive oil sector: a case study on Northern Portugal - Trás-os-Montes. New Medit 2:4-15.

Duarte J., Campos M., Guzmán J.R., Beaufoy G., Farfan M.A., Cotes B., Benítez E., Vargas J.M., Muñoz-Cobo J., 2009. Olivar y biodiversidad. In: J.A Gómez Calero (ed.) Sostenibilidad de la producción de olivar en Andalucía, Consejería de Agricultura y Pesca, Vol. 1. Junta de Andalucía Publ., Sevilla, Spain, pp 162-220.

Duelli P., Obrist M.K., 2003. Biodiversity indicators: the choice of values and measures. Agr. Ecosyst. Environ. 98:87-98.

EEIG Agrosynergie, 2009. Assessment of measures applied to the olive sector in the framework of the Common Agricultural Policy. Study financed by the European Commission. Available from: http://ec.europa.eu/agriculture/eval/reports/oilseeds/ syn_sum_en.pdf

European Commission, 2003. Communication from the Commission to the Council and the European Parliament 2003. Accomplishing a sustainable agricultural model for Europe through the reformed CAP - the tobacco, olive oil, cotton and sugar sectors. Available from: http://ec.europa.eu/agriculture/capreform/com554/554 _en.pdf

European Commission, Directorate-General for Agriculture and Rural Development, 2004. The Common Agricultural Policy explained. Available from: http://ec.europa.eu/ agriculture/publi/capexplained/cap_en.pdf

Eurostat, 2007. Eurostat Farm Structure Survey 2007. Available from: http://epp.eurostat.ec.europa.eu

Eurostat, 2010. Agricultural statistics. Main results - 2008-09. Available from: http://epp.eurostat.ec.europa.eu

FA0, 2009 Available from: http://faostat.fao.org/site/567/DesktopDefault.aspx?PageID $=567$ \#ancor

Finlayson J., 1981. Seasonal distribution, weights and fat of passerine migrants at Gibraltar. Ibis 123:88-95.

Fiorino P., Lombardo N., Marone E., 2005. Il germoplasma olivicolo: un patrimonio da valorizzare. Italus Hortus 2:7-17.

Firbank L.G., 2008. Assessing the ecological impacts of bioenergy proj- ects. BioEnergy Research 1:12-19.

Fleskens L., 2007. Conservation scenarios for olive farming on sloping land in the Mediterranean. Degree Diss., Wageningen University, The Netherlands.

Fleskens L., 2008. A typology of sloping and mountainous olive plantation systems to address natural resources management. Ann. Appl. Biol. 153:283-297.

Fleskens L., de Graaff J., 2006. Future scenarios for olive production systems on sloping land: stakeholder and expert opinions and results from a simulation model. Olivero Project Communication No. 13. Available from: www.olivero.info

Francia J.R., Martínez Raya A., Ruiz S., 2000. Erosión en suelos de olivar en fuertes pendientes. Comportamiento de distintos manejos de suelo. Edafología 7:147-155.

Francia Martínez J.R., Durán Zuazo V.H., Martínez Raya A., 2006. Environmental impact from mountainous olive orchards under different soil-management systems (SE Spain). Sci. Total Environ. 358:46-60.

García-Brenes M.D., 2007. Los impactos ecológicos del cambio estructural. El olivar andaluz. In: J. Sanz (ed.) El futuro del mundo rural. Síntesis, Madrid, Spain, pp 223-241.

Giourga C., Loumou A., Margaris N.S., Theodorakakis M., Koukoulas S., 1994. The olive groves in the Aegean. In: D. Rokos (ed.) Sciences and environment at the end of the century: problems-perspectives. IRCD, NTUA and Alternative Editions, pp 334-344.

Gobbi, M., 2009. Influenza dei caratteri e delle tipologie di uso del suolo sulle comunità di Carabidi. Studi Trent. Sci. Nat. 85:137-140.

Gómez J.A., Battany M.,. Renschler C.S, Fereres E., 2003. Evaluating the impact of soil management on soil loss in olive orchards. Soil Use Manage. 19:127-134.

Gómez J.A., Orgazb F., Villalobos F.J., Fereres E., 2002. Analysis of the effects of soil management on runoff generation in olive orchards using a physically based model. Soil Use Manage. 18:191-198.

Gómez J.A., Romero P., Giráldez J.V., Fereres E., 2004. Experimental assessment of runoff and soil erosion in an olive grove on a Vertic soil in southern Spain as affected by soil management. Soil Use Manage. 20:426-431.

Gómez J.A., Sobrinho T.A., Giráldez J.V., Fereres E., 2009. Soil-management effects on runoff, erosion and soil properties in an olive grove of Southern Spain. Soil Till. Res. 102:5-13.

Gómez-Calero J.A., 2009. Sostenibilidad de la producción de olivar en Andalucía. Consejería de Agricultura y Pesca. Junta de Andalucía Publ., Sevilla, Spain, pp 314.

Gómez-Limón J.A., Riesgo L., 2010. Sustainability assessment of olive grove in Andalusia: A methodological proposal. Proc. 120th EAAE Seminar, Chania, Crete, Greece.

de Graaff, J., Kessler, A., Duarte, F., 2011. Financial consequences of cross-compliance and flat-rate-per-ha subsidies: The case of olive farmers on sloping land. Land Use Policy 28:388-394.

Guzmán-Álvarez J.R., 2005. Territorio y medio ambiente en el olivar andaluz. Consejería de Agricultura y Pesca. Junta de Andalucía Publ., Sevilla, Spain.

Hendricks, L.C., 1995. Almond growers reduce pesticide use in Mercel Country field trial. Calif. Agr. 49:5-10.

Herrick J.E., 2000. Soil quality: an indicator of sustainable land management. Appl. Soil Ecol. 15:75-83.

Hodgson J.G., Montserrat Martí G., Tallowin A.J., Thompson K., Díaz S., Cabido M., Grime J.P., Wilson P.J., Band S.R., Bogard A., Cabido R., Cáceres D., Castro-Díez P., Ferrer C., Maestro-Martínez M., PérezRontomé M.C., Charles M., Cornelissen J.H.C., Dabbert S., Pérezharguindeguy N., Krimly T., Sijtsma F.J., Strijker D., Vendramini F., Guerrero-Campo J., Hynd A., Jones G., Romo-Díez A., De Torres Espuny L., Villar-Salvador P., Zak M.R., 2005. How much will it cost to save grassland diversity? Biol. Conserv. 122:263-273. 
House G.J., Parmelee R.W., 1985. Comparison of soil arthropods and earthworms from conventional and notillage agroecosystems. Soil Till. Res. 5:351-360.

Iannotta N., 2003. La difesa fitosanitaria. pp 393-410 in: P. Fiorino (ed.) Olea trattato di olivicoltura. Edagricole, Bologna, Italy.

Iannotta N., Belfiore T., Brandmayr P., Mazzei A., Noce M.E., Scalercio S., Vizzarri V., 2008. Risposta delle comunità Coleotteri Carabidi dell'oliveto ai sistemi di conduzione biologica e convenzionale. Atti XVIII Convegno Gadio 2008: Un mondo che cambia: successioni ecologiche, invasioni biologiche ed alterazioni antropiche. Studi Trent. Sci. Nat. 86:139-140.

Iannotta N., Belfiore T., Brandmayr P., Noce M.E., Scalercio S., 2006. Impatto sull'ecosistema oliveto di alcuni fitofarmaci «biologici». Inform. Agr. 44:65-68.

Iannotta N., Belfiore T., Noce M.E., Scalerci, S., Vizzarri V., 2007a. The impact of some compounds utilised in organic olive groves on the non-target arthropod fauna: canopy and soil levels. Ecoliva 2007, VI Jornadas Internacionales de Olivar Ecologico, Puente de Génave (Jaén), Spain, Available from: http://www.ecoliva.info/ index. php?option=com_content\&task=blogcategory\&id=17\& Itemid $=38$

Iannotta, N., Belfiore, T., Noce, M.E., Scalercio, S., Vizzarri, V., 2007 b. Ecosistema e interventi contro la mosca. Inform. Agr. 25:59-60.

Iannotta N., Belfiore T., Noce M.E., Scalercio S., Vizzarri V., 2007c. Insetticidi ammessi in biologico, effetti nell'ecosistema oliveto. Inform. Agr. 33:47-50.

Iannotta N., Belfiore T., Brandmayr P., Noce M.E., Scalercio S., 2007d. Evaluation of the impact on entomocoenosis of active agents allowed in organic olive farming against Bactrocera oleae (Gmelin, 1790). J. Environ. Sci. Heal. B 42:783-788.

International Olive Council, 2010. Available from: http://www.internationaloliveoil.org/

ISMEA, 2005. L'olivicoltura italiana nella campagna 2004/2005. Quaderno di filiera. Available from: www.ismea.it

ISMEA, 2007. Available from: www.ismea.it

ISMEA, 2009. Indicatori del sistema agroalimentare italiano - 2009. Available from: http://www.ismea.it/flex/cm/pages/ServeBLOB.php /L/TT/PPagina/244

ISMEA-IPSOA, 2010. Report Economico-Finanziario (REF), 2010 Volume I, Bovini, Cereali, Frutta Fresca, Olio d'Oliva.

ISTAT, 2007a. Available from: http://agri.istat.it

ISTAT, 2007b. Indagine sulla struttura e le produzioni delle aziende agricole (SPA) Anno 2007. http://www.istat.it/dati/dataset/ 20090120_01/tav05anp.html

ISTAT, 2010. Available from: http://agri.istat.it/jsp/dawinci. jsp?q=plC270000010000011000\&an=2010\&ig=1\&ct=311\&id=15Al 21Al32A

Jacomini C., Nappi P., Sbrilli G., Mancini L., 2000. Indicatori ed Indici ecotossicologici e biologici applicati al suolo: stato dell'arte. Agenzia Nazionale per la Protezione dell'Ambiente (ANPA).

Jordano P., Herrera M., 1981. The frugivorous diet of Blackcap populations Sylvia atricapilla wintering in southern Spain. Ibis 123:502507.

Kabourakis E., 1999. Code of practices for ecological olive production system in Crete. Olivae 77:46-55.

Katranidis S.D., Kotakou C.A., 2008. Are CAP Decoupling Policies Really Production Neutral? pp 1-8 in Proc. 12th Congr. European Association of Agricultural Economists, Gent, Belgium.

Kladivko E., 2001. Tillage systems and soil ecology. Soil Till. Res. 61:6176 .

Klingebiel A.A., Montgomery P.H., 1961. Land capability classification. US Government Printing Office, Washington, DC, USA.

Kosmas C., Danalatos N., Cammeraat L.H., Chabart M., Diamantopoulos J., Farand R., Gutierrez L., Jacob A., Marques H., Martinez-Fernandez J., Mizara A., Moustakas N., Nicolau J.M.,
Oliveros C., Pinna G., Puddu R., Puigdefabregas J., Roxo M., Simao A., Stamou G., Tomasi N., Usai D., Vacca A., 1997. The effect of land use on runoff and soil erosion rates under Mediterranean conditions. Catena 29:45-59.

La Mantia T., 2002. L'arboricoltura da legno nel paesaggio siciliano. Quaderni IAED 15:135-153.

Latella L., Gobb M., 2008. La fauna del suolo: tassonomia, ecologia e metodi di studio dei principali gruppi di invertebrati terrestri italiani. Museo Tridentino di Scienze Naturali Ed., Trento, Italy.

Lewis 0.T., 2006. Climate change: Species-area curves and the extinction crisis. Philos. T. Roy. Soc. B 361:163-171.

López-Cuervo S., 1990. La erosión en los suelos agrícolas y forestales de Andalucía. Consejería de Agricultura y Pesca. Junta de Andalucía, Sevilla, Spain, Colección Congresos y Jornadas 17:11-16.

Lo Verde G., Perricone G., La Mantia T., 2002. L'azione di differenti tipi di frangiventi sull'artropodofauna e sulle caratteristiche bioagronomiche di un aranceto nel territorio di Menfi (Ag). Italia Forestale e Montana 4:390-408.

Martínez R.A., Ruiz S., Cárceles B., Durán Z.V.H., Francia J.R., Arroyo P.L., 2002. Comparison of two cultivation techniques in olive plantations with slopes higher than 25\%: green plant cover and no tillage. pp 519-520 in Proc. 7th ESA Congr., Cordoba, Spain.

Massa B., La Mantia T., 1997. Benefits of hedgerows-windbreaks for birds and their valorization in sustainable agriculture. Agricoltura Mediterranea 127:332-341.

Masson J., 2005. Use of Very High Resolution Airborne and Spaceborne Imagery: a Key Role in the Management of Olive, Nuts and Vineyard Schemes in the Frame of the Common Agricultural Policy of the European Union. Information and Technology for Sustainable Fruit and Vegetable Production. pp 709-718 in Proc. FRUTIC 05, Montpellier, France.

McLaughlin A., Mineau P., 1995. The impact of agricultural practices on biodiversity. Agr. Ecosyst. Environ. 55:201-212.

Mili S., 2006. Olive Oil Marketing in Non-Traditional Markets: Prospects and Strategies. New Medit 5:27-37.

Ministero delle Politiche Agricole Alimentari e Forestali, 2010. Piano Olivicolo-Oleario. Roma, Italy.

Morales Bernardino J.M.J., 2002. Sistemi di potatura negli oliveti tradizionali. Olivae 92:38-43.

Morris T., Campos M., 1999. Predatory insects in olive-grove soil. Zool. Baetica 10:149-160.

Munoz-Cobo J. 1990. Evolucion de la avifauna nidificante en olivares viejos de Jaen. Testudo 1:99-117.

Neri D., Lodolini E.M., Cioccolanti T., Panzini G., 2010. L'ecosostenibilità è gestire il suolo al meglio. Olivo e Olio 3:34-39.

Niethammer G., 1966. Handbook der Vögel Mitteleuropas Bearb. K.M. Bauer und G. von Blotzhenn Band I Ed., Frankfurt am Main, Germany.

Nsabimana D., Haynes R.J., Wallis F.M., 2004. Size, activity and catabolic diversity of the soil microbial biomass as affected by land use. Appl. Soil Ecol. 26:81-92.

OECD, 2004. Analysis of the 2003 CAP Reform, OECD, Paris. Available from: http://www.ismea.it/flex/cm/pages/ServeBLOB.php/L/IT/ IDPagina/244

Olea databases. Available from: www.oleadb.it

Oil World, 2005. Oil World Annual. Available from: www.oilworld.biz

Pain D., 1994. Case studies of farming and birds in Europe: olive farming in Portugal. Studies in European Agriculture and Environment Policy No. 9, RSPB, Birdlife International. Available from: www.birdlife.org

Palese A.M., Pasquale V., Celano G., Figliuolo G., Masi S., Xiloyannis C., 2009. Irrigation of olive groves in Southern Italy with treated municipal wastewater: effects on microbiological quality of soil and fruits. Agr. Ecosyst. Environ. 129:43-51. 
Palese A.M., Sofo A., Celano G., Xiloyannis C., 2005. Stoccaggio della C02 ambientale in giovani piante di olivo. pp 431-438 in: Atti Convegno Europeo Il futuro dei sistemi olivicoli in aree marginali: aspetti socio-economici, conservazione delle risorse naturali e produzioni di qualità, 12-13 0ttobre 2004, Matera, Italy.

Pannelli, G., 2006. L'olivicoltura specializzata comincia dalla chioma. Olivo \& Olio, 6:12-18.

Paracchini M.K., Britz W., 2010. Quantifying effects of changed farm practice on Biodiversity in policy impact assessment - an application of CAPRI-Spat. Proc. OECD Workshop Agri-environmental Indicators: Lessons Learned and Future Directions, Leysin, Switzerland.

Parisi V., 2001. La qualità biologica del suolo. Un metodo basato sui microartropodi. Acta Naturalia Ateneo Parmense 37:97-106.

Parisi V., Menta C., Gardi C., Jacomini C., Mozzanica E., 2005. Microarthropod communities as a tool to assess soil quality and biodiversity: a new approach in Italy. Agr. Ecosyst. Environ. 105:323-333.

Parra, F., 1990. La dehesa y el olivar. Enciclopedia de la Naturaleza de España. Deate/Adena-WWF Ed., Madrid, Spain.

Pastor M. 1990. Non-tillage and other methods of reduced tillage in olive cultivation. Olivae 34:18-30.

Pastor M., Castro J., 1995. Soil management systems and erosion. Olivae 59:64-74.

Pastor M., Castro J., Humanes M.D., Munoz J., 2001. Sistemas de manejo del suelo en olivar de Andalucia. Edafologia 8:75-98.

Pizzolotto R., Mazzei A., Belfiore T., Bonacci T., Odoguardi R., Scalercio S., Iannotta N., Brandmayr P., 2008. Biodiversità dei Coleotteri Carabidi (Coleoptera: Carabidae) nell'agroecosistema oliveto in Calabria. Entomologica 41:5-11.

Raglione M., Toscano P., Angelini R., Briccoli Bati C., Spadoni M., De Simone C., Lorenzini P., 1999. Olive yield and soil loss in hilly environment of Calabria (Southern Italy). Influence of permanent cover crop and ploughing. pp 1038-1040 in Proc. 6th Int. Meet. on Soils with Mediterranean Type of Climate, Barcelona, Spain.

Redolfi I., Tinaut A., Pascual F., Campos M., 1999. Qualitative aspects of myrmecocenosis (Hym., Formicidae) in olive orchards with different agricultural management in Spain. J. Appl. Entomol. 123:621-627.

Redolfi I., Tinaut A., Pascual F., Campos M., 2004. Nest density of the ant assemblage (Formicidae) in three olive orchards under different agricultural management in Granada, Spain. Ecologia Aplicada 3:7381.

Rete Rurale Nazionale (RRN), 2010. GAEC WORKSHOP 2010. Technical Report. Roma, Italy. Available from: www.reterurale.it

Rey P.J., 2010. Preserving frugivorous birds in agro-ecosystems: lessons from Spanish olive orchards. J. Appl. Ecol. 48:228-237.

Rodríguez-Lizana A., Espejo-Pérez A. J., González-Fernández P., OrdóñezFernández R., 2008. Pruning residues as an alternative to traditional tillage to reduce erosion and pollutant dispersion in olive groves. Water Air Soil Poll. 193:165-173.

Romero P., Castro G., Gómez J.A., Fereres E., 2007. Curve Number values for olive orchards under different soil management. Soil Sci. Soc. Am. J. 71:1758-1769.

Ruano F., Lozano C., Garcia P., Peña A., Tinaut A., Pascual F., Campos M., 2004. Use of arthropods for the evaluation of the olive-orchard management regimes. Agr. Forest Entomol. 6:111-120.

Saavedra M., 2007. Soil management in olive orchards. In: Production techniques in olive growing. International Olive Council IOC 82:114115 .

Saija R., Franco F.A., 2008. Dalle riforme dell'OCM olio d'oliva e ortofrutta all'istituzione dell'OCM unica: conseguenze e prospettive. Cap. 9, pp 209-245 in: KALìt (ed.) Sviluppo rurale integrato e sostenibile nelle aree marginali in Calabria.

Sala O.E., Chapin III F.S., Armesto J.J., Berlow R., Bloomfield J., Dirzo R., Huber-Sanwald E., Huenneke L.F., Jackson R.B., Kinzig A., Leemans
R., Lodge D., Mooney H.A., Oesterheld M., Poff N.L., Sykes M.T., Walker B.H., Walker M., Wall D.H., 2000. Global biodiversity scenarios for the year 2100. Science 287:1770-1774.

Santi E., Maccherini M., Bonini I., Cortes-Selva F., Pruscini S., Palazzo D., Amici V., Chiarucci, A. 2010. Assessing changes in patterns of vascular plant and bryophyte communities in olive groves. pp 56 in Proc. 7th Eur. Dry Grassland Meet., Smolenice, Slovak Republic.

Santos A.P., Cabanas J.E., Pereira A.J., 2007. Abundance and diversity of soil arthropods in olive grove ecosystem (Portugal): Effect of pitfall trap type. Eur. J. Soil Biol. 43:77-83.

Scalercio S., 2006. Macrolepidotteri rilevati tramite pit- fall traps: sono utili per le analisi ambientali? (Lepidoptera). Boll. Soc. Entomol. Ital. 138:19-43.

Scalercio S., Iannotta N., Brandmayr P., 2007. The role of semi-natural and abandoned vegetation patches in sustaining lepidopteran diversity in an organic olive orchard. Bull. Insectology 60:13-22.

Sofo A., Palese M.A., Celano G., Crecchio C., Xiloyannis C., 2009. Variazioni qualitative e quantitative delle comunità microbiche del suolo in risposta a pratiche agronomiche sostenibili in un oliveto in ambiente semi-arido. pp 64-68 in Atti VII Convegno AISSA Agricoltura, Qualità dell'ambiente e Salute, Ancona, Italy.

Suarez E., Munoz-Cobo J., 1984. Comunidades de aves invernantes en cuatro medios diferentes de la provincia de Cordoba. Donana Acta Vertebrata 11:45-63.

Theodorakakis M.Ch., 1995. Structure, Dynamics and management on islands olive groves. Degree Diss., University of the Aegean, Lesvos, Greece. [in Greek].

Thomas M.B., Wratten S.D., Sotherton N.W., 1991. Creation of 'island' habitats in farmland to manipulate populations of beneficial arthropods: predator densities and emigration, J. Appl. Ecol. 28:906-917.

Tombes, A., Pilli M., Boco M., 2002. Prime valutazioni su intensità e periodicità della potatura nell'olivo. Frutticoltura 10:71-75.

Toscano P., 2000. Gestione del suolo: ciclo delle lavorazioni, inerbimenti e controllo della flora spontanea degli oliveti. pp 73-83 in Atti Convegno Rassegna olio qualità ambiente. Stato della ricerca e della sperimentazione. Rende, CS, Italy.

Toscano P., Briccoli Bati C., Godino G., De Simone C., Raglione M., Lorenzoni P., Angelini, R., Antonuccio, S., 2004. Agronomical and pedological effects of two different soil management methods in a hilly olive-grove of southern Italy. Olivae 102:21-26.

Toscano P., Briccoli Bat, C., Trombino T., 1999. Grass-cover effects on the vegetative and productive state of a young hilly olive-grove. Acta Hortic. 474:181-184.

Toscano P., Casacchia T., Briccoli Bati C., Scazziota B., 2006. Inerbimento temporaneo e permanente in olivicoltura. Inform. Agr. 21:36-39.

Toscano P., Casacchia T., Zaffina F., 2008. Il compostaggio aziendale dei reflui oleari: smaltimento ecocompatibile e recupero di biomasse per la riorganicazione dei suoli. pp 133-136 in Atti Convegno Internazionale Ricerca ed innovazione per la filiera olivicolo-olearia dei Paesi del Mediterraneo, Agrilevante, 18-20 ottobre 2007, Bari, Italy.

van Straalen N.M., 1998. Evaluation of bioindicator systems derived from soil arthropod communities. Appl. Soil Ecol. 9:429-437.

Wardle D.A., 1995. Impacts of soil disturbance on detritus food webs in agro-ecosystems of contrasting tillage and weed management practices. In: M. Begon (ed.) Advances in Ecological Research, Academic Press, New York, NY, USA.

Young I.M., Blanchart E., Chenu C.K., Dangerfirld M., Fragoso C., Grimaldi M., Ingram J., Monrozier L.J., 1998. The interaction of soil biota and soil structure under global change. Global Change Biol. 4:703-712. 